\title{
A Global Analysis of Protein Expression Profiles in Sinorhizobium meliloti: Discovery of New Genes for Nodule Occupancy and Stress Adaptation
}

\author{
Michael A. Djordjevic, ${ }^{1}$ Han Cai Chen, ${ }^{1}$ Siria Natera, ${ }^{1}$ Giel Van Noorden, ${ }^{1}$ Christian Menzel, ${ }^{1}$ Scott \\ Taylor, ${ }^{1}$ Clotilde Renard, ${ }^{2}$ Otto Geiger, ${ }^{3}$ the Sinorhizobium DNA Sequencing Consortium, and Georg F. \\ Weiller $^{1}$ \\ ${ }^{1}$ Genomic Interactions Group, Research School of Biological Sciences, Australian National University, GPO Box 475, \\ Canberra, A.C.T. 2601 Australia; ${ }^{2}$ Laboratoire de Génétique Cellulaire-INRA, Chemin de Borde Rouge-Auzeville BP27, \\ 31326 Castanet Tolosan, France; ${ }^{3}$ Centro de Investigación sobre Fijación de Nitrógeno, Universidad Nacional Autónoma \\ de México, Apdo. Postal 565-A Cuernavaca, Morelos, CP62210, México
}

Submitted 4 November 2002. Accepted 29 January 2003.

A proteomic examination of Sinorhizobium meliloti strain 1021 was undertaken using a combination of 2-D gel electrophoresis, peptide mass fingerprinting, and bioinformatics. Our goal was to identify (i) putative symbiosis- or nutrientstress-specific proteins, (ii) the biochemical pathways active under different conditions, (iii) potential new genes, and (iv) the extent of posttranslational modifications of $S$. meliloti proteins. In total, we identified the protein products of 810 genes (13.1\% of the genome's coding capacity). The 810 genes generated 1,180 gene products, with chromosomal genes accounting for $\mathbf{7 8 \%}$ of the gene products identified (18.8\% of the chromosome's coding capacity). The activity of 53 metabolic pathways was inferred from bioinformatic analysis of proteins with assigned Enzyme Commission numbers. Of the remaining proteins that did not encode enzymes, ABC-type transporters composed $12.7 \%$ and regulatory proteins $3.4 \%$ of the total. Proteins with up to seven transmembrane domains were identified in membrane preparations. A total of 27 putative nodulespecific proteins and 35 nutrient-stress-specific proteins were identified and used as a basis to define genes and describe processes occurring in $S$. meliloti cells in nodules and under stress. Several nodule proteins from the plant host were present in the nodule bacteria preparations. We also identified seven potentially novel proteins not predicted from the DNA sequence. Post-translational modifications such as $\mathrm{N}$-terminal processing could be inferred from the data. The posttranslational addition of UMP to the key regulator of nitrogen metabolism, PII, was demonstrated. This work demonstrates the utility of combining mass spectrometry with protein arraying or separation techniques to

Corresponding author: Michael A. Djordjevic; Genomic Interactions Group; E-mail: Michael@rsbs.anu.edu.au.

Consortium members: Galibert, F., Finan, T. M., Long, S. R., Puhler, A., Abola, P., Ampe, F., Barloy-Hubler, F., Barnett, M. J., Becker, A., Boistard, P., Bothe, G., Boutry, M., Bowser, L., Buhrmester, J., Cadieu, E., Capela, D., Chain, P., Cowie, A., Davis, R. W., Dreano, S., Federspiel, N. A., Fisher, R. F., Gloux, S., Godrie, T., Goffeau, A., Golding, B., Gouzy, G., Gurjal, M., Hernandez-Lucas, I., Hong, A., Huizar, L., Hyman, R. W., Jones, T., Kahn, D., Kahn, M. L., Kalman, S., Keating, D. H., Kiss, E., Komp, C., Lelaure, V., Masuy, D., Palm, C., Peck, M. C., Pohl, T. M., Portetelle, D., Purnelle, B., Ramsperger, U., Surzycki, R., Thébault, P., Vandenbol, M., Vorhölter, F.-J., Weidner, S., Wells, D. H., Wong, K., Yeh, K.-C., and Batut, J. identify candidate genes involved in important biological processes and niche occupations that may be intransigent to other methods of gene expression profiling.

Additional keywords: iron sequestering, MALDI-TOF mass spectrometry, molecular networks, Nex18, reactive oxygen species, TspO.

Complete genome sequencing provides a powerful platform to better understand the function of cells at the molecular level (Galibert et al. 2001). However, it is increasingly clear that gene sequence alone reveals little about the gene function and that function is most clearly associated with the biochemical activities of the gene's protein products and their associated posttranslational modifications. When a complete DNA sequence is available, several high-throughput tools can be used to identify the mRNAs, proteins, and metabolites that are made as a result of the expression of the genome and to understand the molecular networks and fluxes involved in living cells (Colebatch et al. 2002; Godovac-Zimmerman and Brown 2001; Oliver et al. 2002; Perret et al. 1999; Selinger et al. 2000; Wei et al. 2001). Functional proteomics will play a vital role to identify, monitor and analyze these molecular networks at the level of protein expression.

Rhizobia are bacteria capable of establishing a nitrogen-fixing symbiosis with legumes through the formation of root nodules (Spaink 1996, 2000). The genome of the strain used in this study, Sinorhizobium meliloti 1021, has been sequenced (Barnett et al. 2001; Capela et al. 2001; Finan et al. 2001; Galibert et al. 2001), revealing 6,204 protein encoding reading frames in a 6.7-Mbp genome. This genomic information provides a platform to undertake a large-scale proteomic examination of strain 1021. The genome consists of a chromosome of $3.7 \mathrm{Mbp}$ and two mega plasmids of 1.4 and $1.7 \mathrm{Mbp}$ each, called pSymA and pSymB, respectively. The mega plasmids encode many of the genes involved in the establishment of the nitrogen-fixing root nodules on host plants such as Medicago truncatula, including host recognition, invasion, colonization, and symbiosis (Barnett et al. 2001; Finan et al. 2001). Genes that are expressed during nodule occupation also have been well studied using several approaches (Cabanes et al. 2000; Oke and Long 1999; Spaink 2000), but the nature of several basic metabolic processes remains ill defined. Apart from its symbi- 


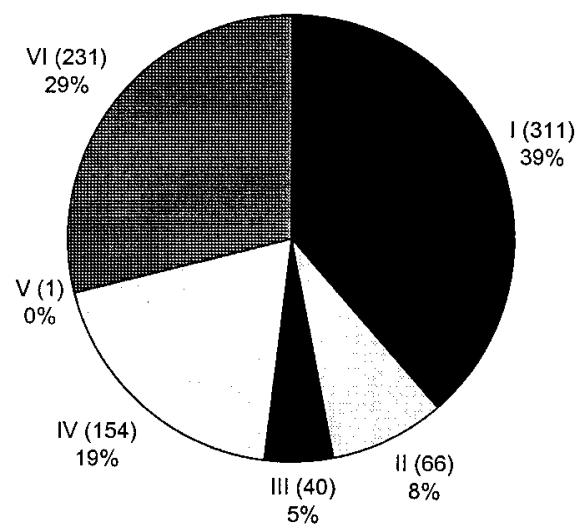

B Comparison of experimental and predicted MW of S. meliloti proteins

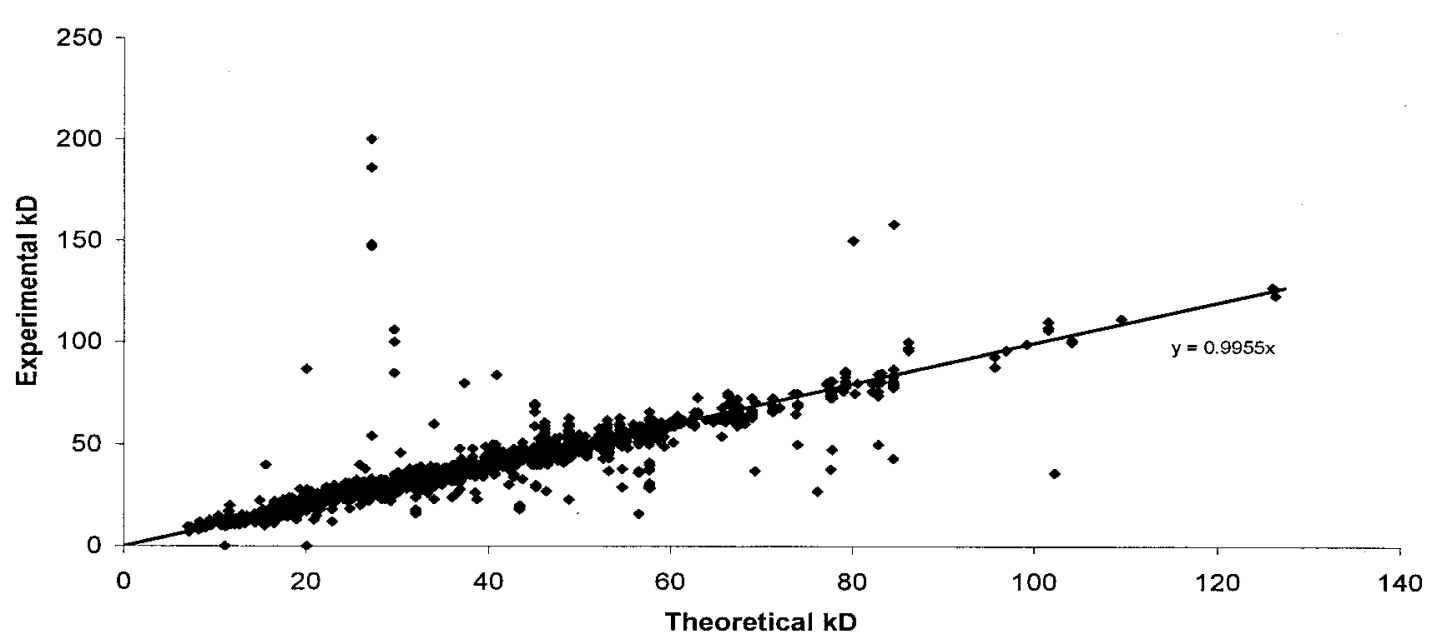

C Comparison of experimental and theoretical pl of S. meliloti proteins

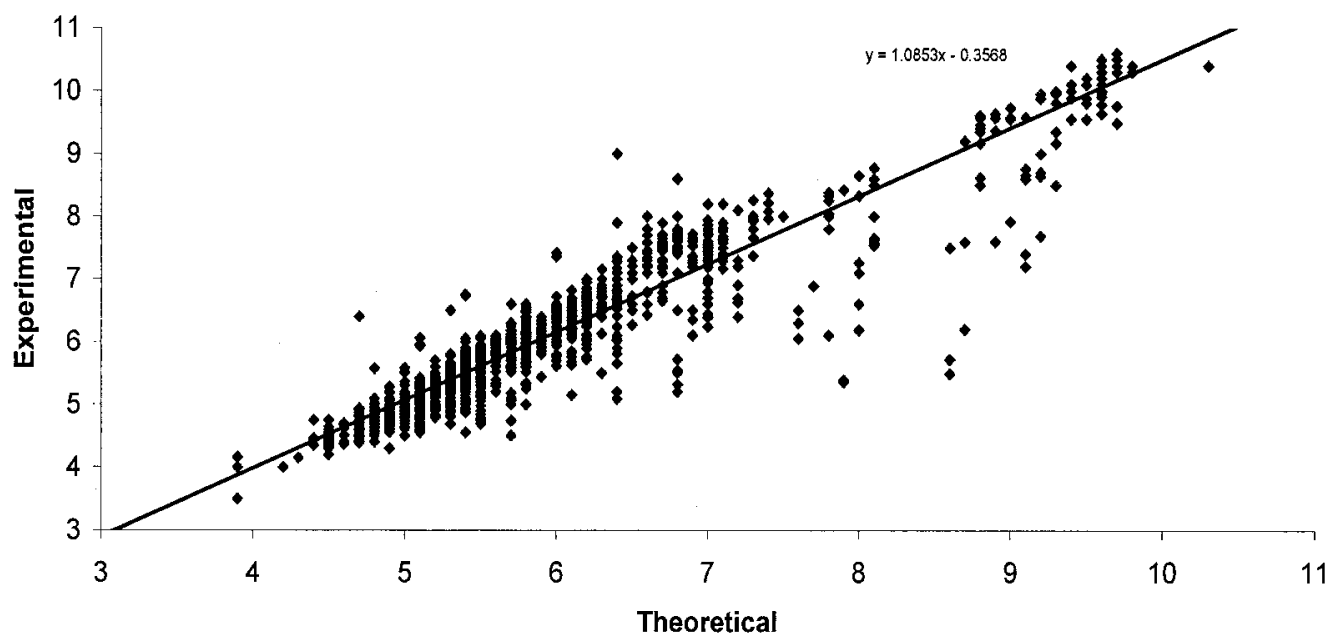

Fig. 1. Analysis of Sinorhizobium meliloti proteins. A, Identified proteins grouped into the categories defined by Riley (1998). I, small molecule metabolism; II, macromolecule metabolism; III, structural elements; IV, cell processes; V, elements of external origin; VI miscellaneous. B, Comparison of the theoretical and experimental molecular mass and molecular weight of each of the 2,224 proteins identified. Consistent with the resolution of the 2-D gel electrophoresis procedures used, very few proteins below $10 \mathrm{kDa}$ or above $100 \mathrm{kDa}$ were visualized. C, Comparison of the theoretical and experimental isoelectric point (pIs) of the 2,224 proteins identified. 
otic capacity, $S$. meliloti also is capable of living in soils and other nutrient-depleted environments for long time periods without the presence of a recognizable host (Milcamps et al. 1998). Mutagenesis studies using a gene-tagging approach have identified 33 genes that appear to be involved in the response of the bacterium to carbon or nitrogen stress (Milcamps et al. 1998) and responses to phosphate stress have been reported (Bardin et al. 1996, 1998; Geiger et al. 1999; McDermott 2000).

We undertook a large-scale examination of the proteome of strain 1021 grown under a range of conditions, including common laboratory and nutrient-depleted media. We also isolated strain 1021 from peribacteroid membranes and from crude nodule preparations. Our first aim was to array on 2-D gels all the protein present from cells grown under defined conditions. We then used peptide mass fingerprinting (PMF), combined with a knowledge of the physical parameters of the protein (e.g., molecular weight $\left[\mathrm{M}_{\mathrm{r}}\right]$ and isoelectric point $[\mathrm{pI}])$ and the predicted open reading frames (ORFs) derived from the DNA sequencing data to identify the proteins present in the soluble and membrane fractions of cells at different phases of growth. Collectively, this data generated a "proteomic baseline" that enabled us to identify the major metabolic pathways and proteins observed in the laboratorygrown cells. Subsequently, we used this information to examine the proteins observed in cells grown under nutrientdeprived conditions (low phosphorous or low carbon) or isolated from root nodules to aid the discovery of novel condition-specific proteins and metabolic activities. Our focus was on identifying novel condition-specific proteins and regulatory circuits; therefore, in this article, we focused on those proteins that showed dramatic changes in abundance. From our observations, proteins that are up- or down-regulated are, in many cases, common metabolic enzymes (Chen et al. 2000). In addition, we also examined the proteins identified for the extent of posttranslational modifications that resulted in either multiple charge isoforms of the same protein or proteins that were derived from a single gene but differed in both mass and charge. The mass spectra of proteins that were unable to be matched to any identified gene then were compared to a six-frame translation of the $S$. meliloti genome to identify proteins that have not been predicted previously. Given that protein identity is a necessary first step to identify pathways, components of protein-protein interactions, and the functions of protein, this analysis represents a major landmark towards the functional proteomic analysis of $S$. meliloti and provides a complementary strategy for other high-throughput global analysis approaches. The conditionspecific proteins identified here will provide new targets for genome-wide mutagenesis studies and a basis to identify the putative function of condition-specific genes.

\section{RESULTS AND DISCUSSION}

Protein expression profiles of the $S$. meliloti replicons.

From an analysis of proteins from all the growth conditions analyzed, PMF identified 2,224 proteins that were derived from 810 distinct $S$. meliloti genes or $13.1 \%$ of the total genomic output. The 810 genes generated a total of 1,180 different gene products, therefore generating an average of 1.4 gene products per gene, a number that is lower than described for other bacteria (Nouwens et al. 2000). Many proteins were identified more than once because they appeared under several conditions; this explains the redundancy in the number of unique proteins identified compared with the proteins analyzed. Many proteins appear as charge isoforms that have no observable mass difference but different pIs. Assuming that the posttranslational modifications that lead to charge alterations are not artifacts, we estimate that the $S$. meliloti genome would encode approximately 8,500 proteins. In addition, nearly $30 \%$ of proteins possess a charge altering posttranslational modification, suggesting that these modifications are common in bacteria and that many avenues for posttranslational control exist. Identification and characterization of these protein modifications will reveal new aspects of function and regulation.

The majority of the proteins identified were derived from chromosomal genes (78\%; 629 species) with 12.5 and $9.8 \%$ being derived from the $\mathrm{pSymB}$ and $\mathrm{pSymA}$, respectively. Of the 3,341 chromosomal genes (Capela et al. 2001), 18.8\% of the predicted proteins were identified. By combining these data with knowledge of the operon structure of the chromosome, an extensive expression profile can be predicted for a significant portion of the chromosome of strain 1021, assuming that proteins expressed from a polycistronic message are present in the cell at the same time. The paucity of matches to genes of either endogenous plasmid suggests that these genes are underexpressed or of low abundance in the conditions tested, or that the products cannot be solubilized or arrayed using 2-D gel electrophoresis (2-DGE). Many very hydrophobic or low-abundance proteins often cannot be detected by current 2-D-based protein arraying and detection strategies. To reveal a higher proportion of the proteins present in a cell will require the examination of cells grown under a wide range of conditions as well as more effective solubilization, arraying, resolution, and detection strategies. Other 2-D gel-independent strategies also are available. All the proteins identified in this study were grouped according to the Riley classification system (Fig. 1A) (Riley 1998).

In all, 421 protein spots matched to 196 different genes classified as "hypothetical" or "unknown" in the S. meliloti genome database (version 16 March 2001) (Fig. 1 A). These results confirmed the existence of the protein products of these genes and indicate that they play an important role in cellular function.

Table 1. List of proteins that occur as multimers after 2-D gel electrophoresis ${ }^{\mathrm{a}}$

\begin{tabular}{lccccrcc}
\hline Gene ID & $\begin{array}{c}\text { Experimental } \\
\mathbf{M}_{\mathbf{r}} \times \mathbf{1 0}^{-\mathbf{3}}\end{array}$ & $\begin{array}{c}\text { Theoretical } \\
\mathbf{M}_{\mathbf{P}}(\mathbf{k D a})\end{array}$ & $\begin{array}{c}\text { Confidence } \\
\text { score }\end{array}$ & $\begin{array}{c}\text { Monomer present } \\
\left(\mathbf{M}_{\mathbf{r}} \times \mathbf{1 0}^{-\mathbf{3}}\right)\end{array}$ & Gravy & TMD & \multicolumn{1}{c}{ Comment } \\
\hline SMc01556 & $148,186,200$ & 27.1 & $1-2$ & Yes; 26 & -0.116 & 1 & Different multimers formed \\
SMa1231 & $85 ; 106$ & 29.6 & 3 & Yes; 28-35 & 0.078 & 0 & Different multimers formed \\
SMc02094 & 158 & 84.5 & 3 & Yes; 79-87 & -0.280 & 4 & Dimer formed \\
SMc00644 & 150 & 80.1 & 3 & No & -0.706 & 1 & Dimer formed \\
SMc00863 & 87 & 20.0 & 3 & No & -0.299 & 2 & Tetramer formed \\
SMc02396 & 80 & 37.3 & 3 & Yes; 35-38 & -0.239 & 3 & Dimer formed \\
\hline
\end{tabular}

${ }^{a}$ In the case of SMc02094, there was no change in isoelectric point of the monomer and multimer. The proteins either possessed strong predicted transmembrane domains or had a high level of aliphatic amino acid residues (positive grand average of hydropathicity [GRAVY] score) and were moderately hydrophobic, suggesting that they were membrane located. $\mathrm{M}_{\mathrm{r}}=$ molecular weight, $\mathrm{M}_{\mathrm{P}}=$ molecular mass, TMD = transmembrane domains. The confidence score is explained in the Methods section. Gene ID refers to the unique gene identification assigned to each $S$. meliloti gene. 
Experimental and theoretical physical protein parameters.

A comparison of the theoretical and experimental molecular masses of the identified proteins (Fig. 1B) should show a good correlation if the algorithms and criteria used for matching peptide fingerprints and proteins in the database were appropriate and, indeed, this was shown to be the case. An examination of the exceptional proteins that were, for example, appreciably larger than predicted (Table 1) showed that they were homogeneous multimers resulting from incomplete alkylation of the cysteine residues during sample preparation, as has been found by Hamdan and associates (2001), and this resulted in an expected small $\mathrm{pI}$ shift when the denatured monomer and multimer of the same protein was present on the same gel. However, in the case of the protein product of SMc02094 (Table 1), there was no change in $\mathrm{pI}$ of the monomer and multimer, and it is possible that strong protein-protein interactions occur between the subunits of this protein.

Proteins with a molecular mass appreciably lower than predicted were breakdown products of the abundant proteins present. Breakdown products occurred together on the same gel as the full-length protein from which they were derived and, as expected, the $\mathrm{pI}$ of these breakdown products varied from that expected for the full-length protein. The highest incidence of breakdown products occurred in the nodule bacteria samples, where truncated products of NifH, NifD, NifK, GroEL, and several other abundant proteins were detected. As expected, the matching peptides in these truncated proteins mapped to distinct regions of the full-length mature protein (Fig. 2A and B). In contrast to the nodule bacteria samples, the presence of putative breakdown products was rare in the samples from laboratory-cultured bacteria. The co-purification of plant proteases with the nodule bacteria is a likely cause of the high incidence of the protein breakdown products, although we cannot discount that these products have some biological role. Proteolytic breakdown occurred in both the crude nodule bacterial preparation and the bacteroid preparation.

The experimentally derived pIs of most proteins matched the predicted theoretical pI closely (Fig. 1C). However, differences were observed and many of these are due to N-terminal processing (Table 2). Of the 12 proteins where the predicted and experimental pIs differed by $>1.4 \mathrm{pH}$ units, 9 were found to be hypothetical proteins, with several predicted to possess $\mathrm{N}$-terminal processing. In these proteins, the peptide matches were restricted to the $\mathrm{C}$-terminal end of these proteins regardless of whether or not they possessed a predicted signal sequence (Fig. 2C). In the cases where a substantial pI deviation occurred and there was no evidence of $\mathrm{N}$-terminal processing, several possibilities exist to explain this observation: (i) the protein was incorrectly assigned by fingerprinting analysis, (ii) posttranslational modifications that alter protein charge were responsible for the change in pI, (iii) the start site or correct frame in the $\mathrm{N}$-terminus was incorrectly assigned, or (iv) multiple protein products were derived from the same transcript, as in the case of Bradyrhizobium japonicum NolA (Loh et al. 1999). Of the 12 proteins identified in Table 2, 9 were derived from hypothetical genes where ORF assignment is likely to be less firm. Internal and N-terminal sequencing of these proteins is required to resolve these issues and may lead to reassignment of ORFs in some cases.

Identification

of new potential genes and unmatched samples.

We identified seven potentially new S. meliloti ORFs in the S. meliloti genome and one additional ORF at position 89535

\section{A. SMa0827- NifD (Nitrogenase Fe-Mo $\alpha$-chain EC1.18.6.1) \\ 1 MSLDYENDNA LHEKLIEEVL SHYPDKAAKR RKKHLSVAKN KQETAEEGQV VSECDVR SNI KSIPGVMTIR \\ 71 GCAYAGSKGV VUGPIKDMVH ISHGPVGCGQ YSUSQR RYY VGTTGIDAFV TMQFTSDFQE RDIVFGGDKK \\ 141 LEKIIDEIEE LFPLNNGVTV QSECPIGLIG DDIEAVSRKK AEEYKTTIVP VRCEGFRFVS QSLGHHIAND \\ 211 AIRDWVFDTT EVAYEAGR YD VNVIGDYNIG GDAUASR ILL EEIGLHVVGN USGDATLAE I ER APTAKLNL \\ 281 IHCYRSMNYI CRHMEEKTGV PUMEYNFFGP SQIEASLR AKI AKFGPEIEE RAERVIAKYS GLTDAVIDKY \\ 351 WPRLHGKR IM LYVGGLRPR H VITAYEDLGM EIVGTGYEFA HNDDYQRTGH YVKEGTLIYD DVTGYELEK \\ 421 IERIRPDLVG SGIKEKYSVQ KMGIPFR $2 M H$ SWDYSGPYHG YDGFAIFARD MDLAVNNPVU DLYDAPUQKV \\ 491 TMPAASGAAE}

B. SMa0827- NifD (Nitrogenase Fe-Mo $\alpha$-chain EC1.18.6.1) breakdown product

1 MSLDYENDNA LHEKLIEEVL SHYPDKAAKR RKKHLSVAKN KQETAEEGQV VSECDVKSNI KSIPGVMTIR 71 GCAYAGSKGV VUGPIKDMVH ISHGPVGCGQ YSUSQRRNYY VGTTGIDAFV TMQFTSDFQE KDIVFGGDKK 141 LEKIIDEIEE LFPLNNGVTV QSECPIGLIG DDIEAVSRKK AEEYKTTIVP VRCEGFR FVS QSLGHHIAND 211 AIR DUVFDTT EVAYEAGR VD VNIGDYNIG GDAWASRILL EE IGLHVVGN WSGDATLAEI ER APTAKLNL 281 IHCYRSMNYI CRHMEEKYYGV PWMEYNFFGP SQIEASLRQI AKFFGPEIEE RAERVIAKYIS GLTDAVIDKY 351 UPRLHGKRVM LYVGGLRPRH VITAYEDLGM EIVGTGYEFA HNDDYQRTGH YVKEGTLIYD DVTGYELEKF 421 IERIRPDLVG SGIKEKYSVQ KMGIPFRQMH SUDYSGPYHG YDGFAIFARD MDLAVNNPVU DLYDAPUQKV 491 TMPAASGAAE

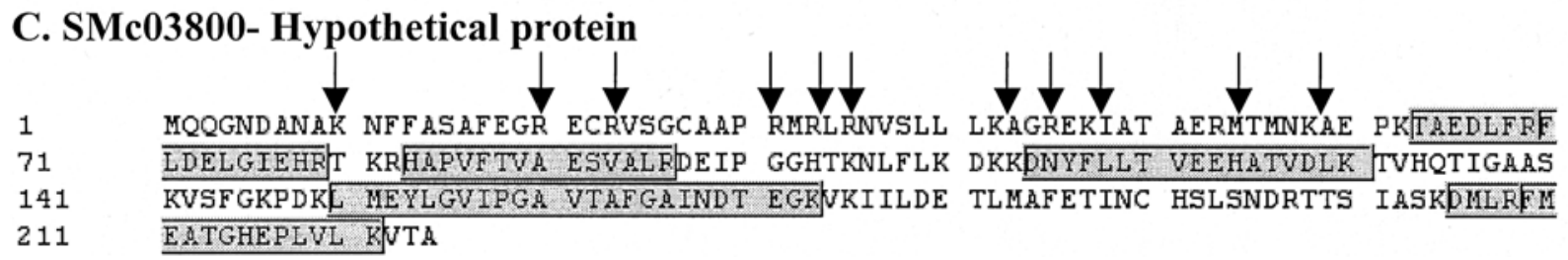

Fig 2. Matching peptides in three Sinorhizobium meliloti proteins. A and B, Coverage of peptides obtained with a full-length NifD (16 matching peptides; experimental isoelectric point $[\mathrm{pI}] 5.4$; molecular weight $\left.\left[\mathrm{M}_{\mathrm{r}}\right] 56,000\right)$ compared with a putative breakdown product of NifD that was calculated to be 19 $\mathrm{kDa}$ shorter than the full-length product (7 matching peptides; experimental $\mathrm{pI} 5.6 ; \mathrm{M}_{\mathrm{r}}$ 37,000). The lack of matching peptides in the $\mathrm{C}$ and $\mathrm{N}$ termini in the putative breakdown product is consistent with the lower molecular weight. C, Matching peptides of the hypothetical protein SMc03800 (experimental pI 6.2; $\mathrm{M}_{\mathrm{r}} 18,000$ versus theoretical pI 8.3; molecular mass $\left[\mathrm{M}_{\mathrm{p}}\right] 25 \mathrm{kDa}$ ); the arrows indicate possible cleavage sites for trypsin in the N-terminus. 
of the reverse strand of pSymA, which has a 25-amino-acid (aa) extension of SMa0162 (Table 3). The first 52 aa of the new ORF at position 2313225 are very similar to the N-terminus of SMc01467 (signal peptide hypothetical partial homology) and SignalP predicts a high-probability N-terminal cleavage site between amino acids 47 and 48 . However, given the similarity of this ORF to SMc01467, if this protein exists, it is more likely that it is translated from the methionine at position 21. There was good congruence between the experimental and theoretical $\mathrm{pI}$ and $\mathrm{M}_{\mathrm{r}} / \mathrm{M}_{\mathrm{P}}$ (molecular mass) values for the putative new proteins (Table 3). One putative ORF was perfectly duplicated in two locations on the pSymA (positions 1227477 and 901827).

Fifty-five samples that yielded moderate to good mass spectra could not be matched to any S. meliloti protein. Half of these resulted from protein spots isolated from nodule bacteria and, hence, could be plant proteins. Indeed, a comparison of the fingerprint data to predicted proteins from the $M$. truncatula data base yielded good matches to common nodule and root proteins (Mathesius et al. 2001; Natera et al. 2000), including the ATP synthase subunit (TC15434), protein disulfide isomerase ( $p d i$; TC15518), endoplasmic reticulum HSC70 cognate binding protein precursor (TC15525), putative mitochondrial processing peptidase (TC15519), several leghemoglobins (TC18660, TC18858, and TC22418), and several unknown proteins (TC16044, TC18065, and BG582221). Some of the unmatched $S$. meliloti proteins may represent products of new ORFs or proteins that are highly modified by posttranslational modification that precludes matching. The extent of plant protein contamination of the nodule bacteria preparations was low because the plant proteins identified were not abundant proteins, indicating that the massive amplification of bacterial numbers in the nodule leads to the proteome being dominated by bacterial proteins (Natera et al. 2000).

\section{Metabolic activity profiles in $\mathbf{S}$. meliloti.}

Of the 810 genes matched, 293 gene products are assigned EC numbers in the $S$. meliloti database. These numbers were used to search the Kyoto Encyclopedia of Genes and Genomes (KEGG) database for possible pathways. A pathway was deemed potentially active in $S$. meliloti when a minimum of three different enzymatic activities represented in that pathway was identified although, in several cases, enzymes of a complete or near-complete pathway were identified. Using this definition, 53 pathways involved in many common anabolic and catabolic cellular processes of small molecule metabolism can be considered active in $S$. meliloti under the conditions examined. Many expected pathways were present. For example, the enzymes for the reduction of dinitrogen to ammonia (EC 1.18.6.1) and its conversion to various nitrogenous compounds such as amino acids via several different branches of nitrogen metabolism (EC 6.3.1.2, EC 1.4.1.13, EC 2.1.2.10, and EC 4.4.1.8) were observed in nodule bacteria, but enzymes for the reduction of nitrate or nitrous oxide were not detected under any of the conditions examined. Enzymes for many "housekeeping" pathways were active, including nucleic acid, fatty and amino acid biosynthesis and catabolism, selenoamino acid metabolism, the synthesis of several vitamins (thiamine, riboflavin, B6, pantothenate, biotin, folate, and B12), porphyrin (heme) and the macromolecules, peptidoglycan, lipopolysaccharide, RNA, DNA, several aminoacyl-tRNAs, and ribosomal RNA proteins. Several proteins potentially involved in symbiosis are included in Figure 3, and a comparison of the pathways present in cultured cells and nodules is presented below.

The database was subdivided into proteins that were present either in laboratory-grown media, under nutrient stress, or in nodule bacteria. Among the 53 identified pathways, no housekeeping pathway was found to be expressed exclusively in nodule or nutrient-stressed bacteria and this led us to examine for putative differential expression of individual gene products (discussed below). However, it is clear that a large number of proteins present in cultured cells are not represented in nodules (Natera et al. 2000), and this is discussed in more detail below. The pathways for selenoamino acid were active under several conditions; therefore, this type of protein modification is not only likely to be common but also should be considered in de-

Table 2. Chromosomal proteins where experimental isoelectric point (pI) and predicted (Pred.) pI differ by greater than $1.4 \mathrm{pH}$ units

\begin{tabular}{|c|c|c|c|c|c|c|}
\hline 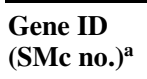 & $\begin{array}{l}\text { Confidence } \\
\text { score }\end{array}$ & $\begin{array}{l}\text { Experimental } \\
\mathrm{p} \mathbf{I} / \mathrm{M}_{\mathrm{r}} \times \mathbf{1 0}^{-3 \mathrm{~b}}\end{array}$ & $\begin{array}{l}\text { Pred.pI/M } \\
\text { kDa }\end{array}$ & $\begin{array}{l}\text { Pred. signal } \\
\text { sequence }\end{array}$ & $\begin{array}{l}\text { Pred. } \mathrm{pI} / \mathrm{M}_{\mathrm{P}}(\mathrm{kDa}) \\
\text { of mature protein }^{\mathrm{c}}\end{array}$ & Comment \\
\hline 00145 & 2 & $6.2 / 16$ & $8.9 / 19$ & No & $\ldots$ & $\begin{array}{l}\text { Hypothetical protein; only C-terminal peptides } \\
\text { matched }\end{array}$ \\
\hline 00651 & 2 & $6.6 / 15$ & $8.6 / 21$ & Yes & $6.5 / 18$ & $\begin{array}{l}\text { Hypothetical protein; only C-terminal peptides } \\
\text { matched }\end{array}$ \\
\hline 01137 & 3 & $5.7 / 28$ & $8.8 / 19$ & Yes & $6.4 / 16$ & $\begin{array}{l}\text { Transmembrane hypothetical protein; only C- } \\
\text { terminal peptides matched }\end{array}$ \\
\hline 01414 & 3 & $7.2 / 49$ & $9.3 / 46$ & Weak $^{\mathrm{d}}$ & $7.9 / 43$ & $\begin{array}{l}\text { Hypothetical protein; only C-terminal peptides } \\
\text { matched }\end{array}$ \\
\hline 01514 & 3 & $5.4 / 15$ & $8.1 / 15$ & Yes & $5.8 / 12.7$ & $\begin{array}{l}\text { Conserved hypothetical protein; only C-terminal } \\
\text { peptides matched }\end{array}$ \\
\hline 01556 & 2 & $5.2 / 15$ & $7.5 / 27$ & Yes & $5.6 / 24$ & $\begin{array}{l}\text { Conserved hypothetical protein; only C-terminal } \\
\text { peptides matched. }\end{array}$ \\
\hline 01769 & 3 & $6.1 / 45$ & $8.3 / 49$ & No & $\ldots$ & $\begin{array}{l}\text { Hypothetical protein; only C-terminal peptides } \\
\text { matched }\end{array}$ \\
\hline 01906 & 2 & $7.7 / 13$ & $9.6 / 9$ & No & $\ldots$ & $\mathrm{Hrm}^{\mathrm{e}}$ \\
\hline 02121 & 3 & $8.6 / 22$ & $7.2 / 29$ & No & $\ldots$ & $\mathrm{AapP}^{\mathrm{e}}$ \\
\hline 02519 & 3 & $8.0 / 40$ & $6.9 / 39$ & No & $\ldots$ & Peptide matches across entire protein ${ }^{\mathrm{e}}$ \\
\hline 02555 & 1 & $6.1 / 17$ & $8.3 / 16$ & Yes & $6.8 / 14$ & $\begin{array}{l}\text { Signal peptide conserved hypothetical protein; } \\
\text { only C-terminal peptides matched }\end{array}$ \\
\hline 03800 & 3 & $6.2 / 18$ & $8.3 / 25$ & No & $\ldots$ & $\begin{array}{l}\text { Hypothetical protein; only C-terminal peptides } \\
\text { matched }\end{array}$ \\
\hline
\end{tabular}

\footnotetext{
${ }^{\mathrm{a}} \mathrm{SMc}$ No refers to the assigned chromosomal locus number.

${ }^{\mathrm{b}} \mathrm{M}_{\mathrm{r}}=$ molecular weight.

${ }^{\mathrm{c}}$ The $\mathrm{pI}$ and molecular mass (Mp) of the predicted mature protein, after removal of the N-terminal signal peptide, was recalculated using the compute $\mathrm{pI} / \mathrm{Mw}$ tool at the Expasy website.

d A low-probability N-terminal cleavage site occurs between amino acids 22 and 23.

${ }^{\text {e }}$ Proteins where post-translational modification is more likely to be responsible for the changes in $\mathrm{pI}$.
} 
vising computer programs used to match peptide masses derived from mass spectrometry.

\section{Proteins involved \\ in transport processes and cell surface structures.}

Of the proteins identified that did not possess enzymatic functions, 268 proteins were identified as ABC ATP binding transporters, ABC-type periplasmic binding proteins, or "binding proteins" with N-terminal signal sequences. These proteins resulted from 103 unique genes, forming the largest group of proteins identified $(12.7 \%$ of the total number of unique proteins). $S$. meliloti encodes $430 \mathrm{ABC}$ transport system genes (Finan et al. 2001) and this study has identified $23.9 \%$ of the protein products of these genes. Many periplasmic binding proteins occurred as multiple charge isoforms on the 2-D gels, but the basis for the charge variation was not identified. The putative import systems identified include those for sugar compounds (including lactose, sorbitol, mannitol, trehalose or maltose, and $\alpha$-glucosides), amino acids, peptides, or amides (including spermidine, rhizopine, putrecine, glycine betaine, and both general and specific systems for branched chain amino acids), ions (zinc, iron, molybdate, sulfate, and phosphate), and C4-dicarboxylate and choline. A specific selection of transport proteins was present in nodule bacteria (discussed below).

In all, 32 proteins (derived from nine unique genes) were involved in iron sequestering (SMb21432, SMc00784, SMc01657, SMc02509, SMc02510, and SMc04317) or transport (SMb21431, SMc02508, and SMc02726) and were expressed under a range of conditions, including nodule occupation and nutrient stress (Fig. 3). The availability of free iron is low in plants and iron sequestering is important for pathogenesis (Simpson et al. 2000). It appears that both SitA and FbpA play roles in sequestering iron during symbiosis, although they also are present under other conditions (Fig. 3).

Transporters of putative function formed the largest group and included SMc04135, which was detected only in nodule bacteria (Fig. 3). A penicillin-binding protein also was identified in cultured cells. Several proteins thought to be part of a specific transporter complex were identified; however, there were few matches to integral membrane (permease) subunits of the transporter complexes (only one permease, SMa2203, was identified). Biochemical studies will need to be done to define the functions of the putative transporter systems and to gain a fuller appreciation of the compounds that can be utilized by strain 1021 under different conditions.
Proteins involved in export processes or the elaboration of cell surface structures were found under several conditions and included SecA, SecB (type I protein export), RkpU and RkpK (SMc02274 and SMc02641), and the multidrug efflux pumps SMc02868, SMc03168, and MexE2 (SMc03972) (Fig. 3 ). SecB was found in nodule bacteria, suggesting that the type I secretion system operates during symbiosis. S. meliloti does not encode a recognizable type III secretion system (Galibert et al. 2001) and, should proteins be translocated to the host from the bacterium during symbiosis, it will be of interest to determine if and how this is achieved. Some auxiliary proteins of the $\mathrm{ABC}$ secretion systems that facilitate the export of large macromolecules such as TolC (SMc02082) also were identified, but this protein was not detected in nodule bacteria. Curiously, two putative exported proteins, SMb21600 and SMb21259, were found in the cellular preparation, casting some doubt on their assignment as exported proteins.

\section{Regulatory proteins.}

Seventy proteins identified had regulatory activity and these resulted from 37 unique genes (3.8\% of the proteins identified) (Table 4). Contrary to the notion that 2-DGE is unable to detect low-abundance regulatory proteins, 26 proteins were identified as transcriptional regulators. The protein spots yielding these results gave a moderate staining intensity, which led us to speculate that they represent repressors rather than transcriptional activators. If this speculation is correct, these proteins are likely to regulate global networks and mutagenesis of these genes should yield important insights into the control of overall cellular metabolism.

The regulatory proteins of interest to symbiosis identified were ActR (SMc02584, a global regulator); PhrR (SMc01110, a regulator of $\mathrm{pH})$; ChvI (SMc02560), which is part of a twocomponent regulatory system regulating succinoglycan synthesis (Cheng and Walker 1998); SyrB and SyrB-like proteins (SMa1698 and SMa0806), thought to be repressors that regulate nod gene expression (Barnett and Long 1997); NtrC (SMc01043), which binds to several promoters and regulates glutamine synthase expression and activity (Fig. 3) (Patriarca et al. 1994); and the putative response regulator (SMb21115). Only one NtrC product was identified in cultured bacteria grown in minimal medium and we do not know if this represents the phosphorylated or nonphosphorylated form of the protein. Ten of the transcriptional regulatory proteins identified were highly basic $(\mathrm{pI}>8)$.

Table 3. List of putative new open reading frames (ORFs) that were not assigned by DNA sequence analysis of the Sinorhizobium meliloti strain $1021^{\mathrm{a}}$

\begin{tabular}{|c|c|c|c|c|c|c|}
\hline Putative ORF coordinates $^{\text {b }}$ & $\begin{array}{l}\text { Experimental } \\
\mathrm{pI} / \mathrm{M}_{\mathrm{r}} \times \mathbf{1 0}^{-3}\end{array}$ & $\begin{array}{l}\text { Theoretical } \\
\text { pI/M } \mathbf{M}_{\mathrm{P}}(\mathrm{kDa})\end{array}$ & $\begin{array}{l}\text { Confidence } \\
\text { score }\end{array}$ & $\begin{array}{l}\text { Coverage }(\%) / \text { no. } \\
\text { matching peptides }\end{array}$ & $\begin{array}{l}\text { No. times } \\
\text { matched }\end{array}$ & Comment \\
\hline \multicolumn{7}{|l|}{ Chromosomal ORFs } \\
\hline 2313225-2312869, MLNSS....VPPKP & $5.1 / 11$ & $5.5 / 13$ & 2 & $34 / 3$ & 1 & $\begin{array}{l}\text { Novel ORF. Homology } \\
\text { to SMc01467 }\end{array}$ \\
\hline $\begin{array}{l}\text { 2996101-2995208, M(I)PPER..IGFPE } \\
\text { pSymB ORFs }\end{array}$ & $5.7 / 29$ & $5.5 / 33$ & 2 & $34 / 7$ & 1 & Novel ORF \\
\hline $\begin{array}{l}\text { 1641462-1642208, MPASS...LADPH } \\
\text { pSymA ORFs }\end{array}$ & $6 / 22$ & $6.0 / 27$ & 1 & $25 / 4$ & 1 & Novel ORF \\
\hline $\begin{array}{l}\text { 907347-907640, MDDDV ...LMVKE } \\
1227477-1227740,901827-901564,\end{array}$ & $6.1 / 6.5$ & $5.1 / 11$ & 1 & $31 / 3$ & 1 & Novel ORF \\
\hline M(L)ITGC ...RAEFR ${ }^{\mathrm{c}}$ & $4.6 / 10$ & $5.4 / 10$ & 1 & $57 / 3$ & 1 & Novel ORF \\
\hline 1317271-1316714, M(L)AEIG...RSLKQ & $6.6 / 20$ & $6.5 / 20$ & 2 & $25 / 4$ & 1 & Novel ORF \\
\hline 352477-352181, M(L)VRRT...VEFGA & $5.3 / 12$ & $5.6 / 11$ & 1 & $37 / 3$ & 1 & Novel ORF \\
\hline 89535-89278, M(I)SGSP...NVALS & $6.5 / 13$ & $6.8 / 9$ & 1 & $55 / 4$ & 1 & $\begin{array}{l}25 \text { amino acid extension } \\
\text { of SMa0162 }\end{array}$ \\
\hline
\end{tabular}

\footnotetext{
${ }^{\mathrm{a}} \mathrm{pI}=$ isoelectric point, $\mathrm{M}_{\mathrm{r}}=$ molecular weight, $\mathrm{M}_{\mathrm{P}}=$ molecular mass .

b Map coordinates measured from nucleotide 1 on each replicon. If the end position is numerically lower than the start position, the ORF is on the reverse strand.

${ }^{c}$ The putative ORF is perfectly duplicated at two map positions on pSymA.
} 
Other regulators identified act at the protein level, including the chemotaxis regulator, CheY2 (SMc03011); the PII proteins involved in nitrogen regulation ( $\mathrm{GlnB}$ and $\mathrm{GlnK})$, both of which occurred as charge isoforms (discussed below); the nitrogen regulatory IIa protein, PtsN, which is a component of the phosphoenolpyruvate:sugar phosphotransferase system
(PTS) for translocating sugars into the cell; and Rnk (SMc00347), a regulator of nucleoside diphosphate kinase. The putative DnaK suppressor protein, DksA (SMc00469) (Table 4 ), is thought to regulate the production of a quorum-sensing dependent virulence factor in Pseudomonas aeruginosa (Branny et al. 2001) and affects pathogenesis of Shigella flex-

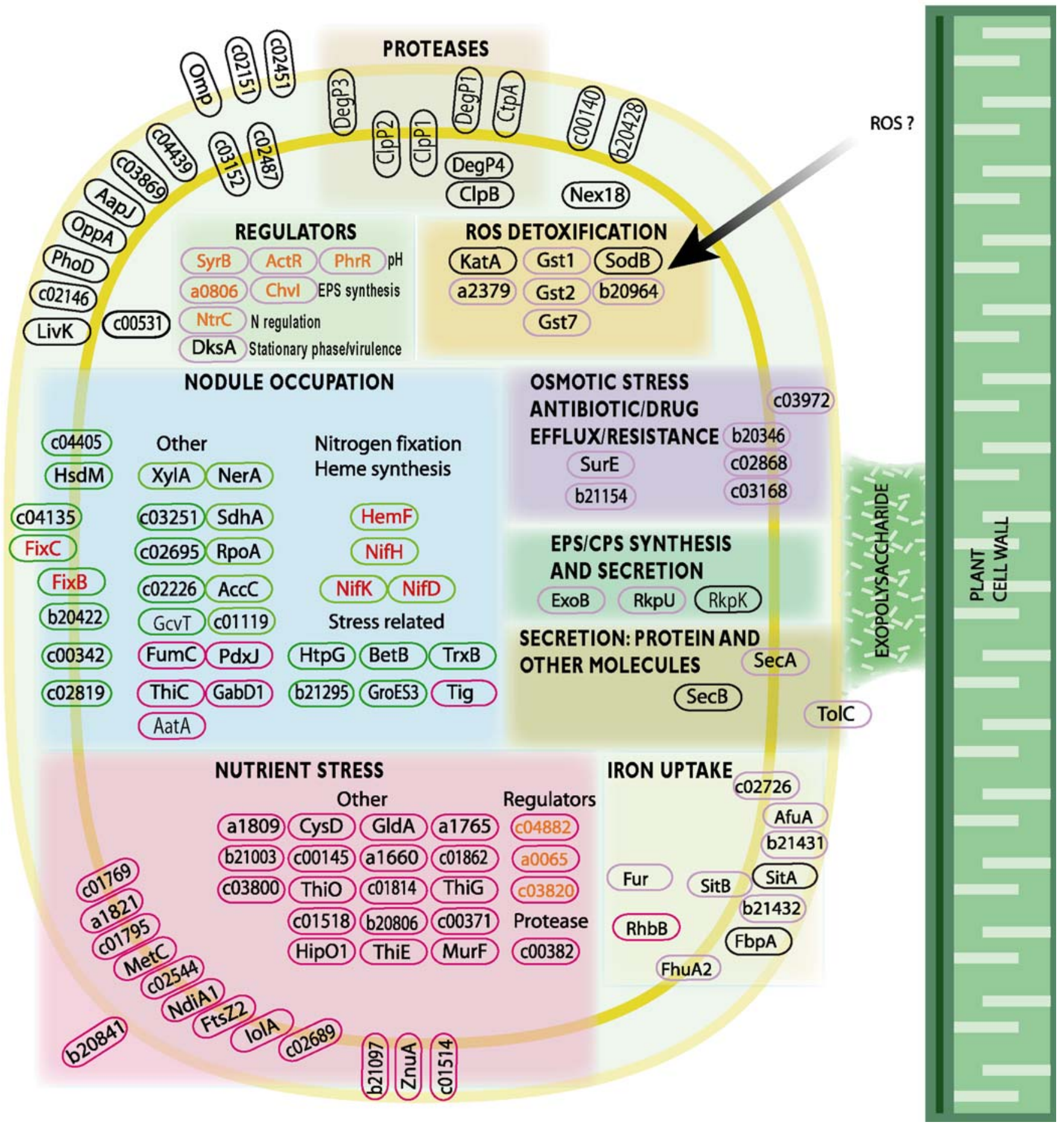

Fig 3. Overview of the genes modulated in Sinorhizobium meliloti during nodule occupation or nutrient stress. A model S. meliloti cell in the vicinity of a plant nodule cell is shown. Gene products are represented by rounded rectangles or, alternatively, the gene identification number is shown (a2379 represents SMa2379, and so on). Transcriptional regulators are depicted in orange text. Gene products detected only in nodule bacteria or under nutrient stress occur predominantly within the blue and crimson boxes, respectively. Putative nutrient stress-specific proteins occur with red, rounded rectangles and nodule-specific proteins in green, rounded rectangles. Proteins in black, rounded rectangles occur in nodule bacteria but are not unique to these cells. Proteins in mauve rectangles could play a role in symbiotic processes. Some proteins (e.g., ThiC and Tig) were found in two conditions; RhbB is a nutrient-stress-specific protein involved in iron uptake. The putative subcellular locations of the proteins are shown with membrane-spanning proteins drawn over the yellow inner membrane and periplasmic proteins drawn in the space between the inner and outer membranes. ROS $=$ putative reactive oxygen species. (Based upon Simpson et al. 2000). 
neri (Mogull et al. 2001). Recently, DksA has been identified as a co-regulator with ppGpp of RpoS in Escherichia coli (Brown et al. 2002; Hirsch and Elliott 2002). DksA is thought to act at a posttranslational level. Although Sinorhizobium meliloti does not possess a recognizable RpoA, mutations affecting ppGpp synthesis have multiple effects upon symbiosis (Wells and Long 2002). It will be of interest to see if the dual control of the stringent response occurring in E. coli by ppGpp and DksA is conserved in S. meliloti, presumably via another regulator or regulators. If so, this would suggest that strains with mutations in DskA would have similar pleiotropic effects to mutants affected in ppGpp synthesis.

\section{Proteases and protection responses.}

Fifty matches to proteases were obtained from 13 unique genes, and these were found under many conditions. Several proteases occurred as charge isoforms and several are predicted to be periplasm located (DegP1, 2, and 3, and CtpA). Several proteases were present in nodule bacteria but were not unique to these cells (Fig. 3). Proteases, including Lon, play a role in establishing symbiosis (Summers et al. 2000). Proteases have been shown to be essential elements of the complex regulatory networks that enable cells to maintain viability under adverse environmental conditions and play a major role in the virulence of several pathogens (Gottesman 1996). The aminopeptidase SMc00382 was found under nutrient deprivation conditions only.

Twenty-five proteins derived from 13 unique genes were identified that were involved in protection responses to reactive oxygen species. It is possible that reactive oxygen species are encountered in host interactions because SodB and KatA were abundant proteins in nodule bacteria but were not unique to these conditions (Fig. 3). The putative haloperoxidase, SMa1809, was detected only in nutrient stressed cells (discussed below) (Fig. 3).

\section{Analysis of proteins in the membrane fraction.}

Of the 323 protein samples from the membrane protein fractions, 248 were identified and matched to 146 genes. These proteins were extracted from strain 1021 cells grown to stationary phase in the rich, tryptone-containing TA medium. Of the 146 proteins, 73 were found only in the membrane preparations, indicating that the conditions used to extract the membrane proteins were capable of solubilizing additional proteins. Using the Tmpred and Protparam programs, the number of predicted transmembrane domains represented in the proteins from the membrane preparations was found to range from 0 to 7 and the Gravy scores ranged from -0.699 (hydrophilic) to 0.255 (moderately hydrophobic) (Fig. 4). There was no correlation between the numbers of transmembrane domains and the Gravy score obtained $\left(R^{2}=0.0073\right)$. Present in the membrane preparations were many outer and inner membrane proteins, including transmembrane proteins, proteins involved in electron transfer and secretion, two protease precursors and a signal peptidase, the flagella hook protein, several periplasmic binding proteins with predicted transmembrane domains (e.g., the phosphate and iron binding proteins, SMc02146 and SMc02509), ABC transporter ATP binding proteins, and several hypothetical proteins with predicted transmembrane domains. However, highly hydrophobic proteins (e.g., the membrane located exopolysac-

Table 4. Regulatory proteins identified ${ }^{\mathrm{a}}$

\begin{tabular}{|c|c|c|c|c|}
\hline Gene ID & $\mathrm{M}_{\mathrm{P}}(\mathbf{k D a})$ & pI & Confidence score & Description \\
\hline SMa0065 & 25.9 & 6.6 & 1 & Putative GntR-family transcriptional regulator \\
\hline $\mathrm{SMa0181}$ & 7.2 & 6.4 & 2 & Probable CspA5 cold shock protein transcriptional regulator \\
\hline SMa0738 & 7.1 & 7.3 & 2 & Probable CspA6 cold shock protein transcriptional regulator \\
\hline SMa0806 & 16.8 & 9.6 & 2 & Probable SyrB-like regulator \\
\hline SMa1698 & 16.6 & 10 & 2 & SyrB regulatory protein \\
\hline SMb20626 & 35.7 & 7.7 & 1 & Putative transcriptional regulator, $\mathrm{AraC}$ family \\
\hline SMb21115 & 18.2 & 9.3 & 2 & Putative response regulator \\
\hline SMb21117 & 16.5 & 9.7 & 2 & Putative transcriptional regulator \\
\hline SMb21270 & 17.0 & 5.1 & 3 & Putative transcriptional regulator \\
\hline SMb21464 & 29.1 & 9 & 3 & Putative transcriptional regulator, GntR family \\
\hline SMc00131 & 18.8 & 7.3 & 3 & Transcription regulator \\
\hline SMc00289 & 21.4 & 7.7 & 3 & Transcription regulator cold shock protein (cspA5) \\
\hline SMc00347 & 14.3 & 6.5 & 3 & Regulator of nucleoside diphosphate kinase $(r n k)$ \\
\hline SMc00469 & 16.2 & 5.3 & 1 & DnaK suppressor protein (DksA) \\
\hline SMc00698 & 10.4 & 6.7 & 3 & Transcription regulator \\
\hline SMc00943 & 20.7 & 6.6 & 3 & Trp repressor binding protein homologue (wrbA) \\
\hline SMc00947 & 12.3 & 5.3 & 3 & Nitrogen regulatory protein pII $(g \ln B)$ \\
\hline SMc01043 & 53.8 & 6 & 3 & Nitrogen assimilation regulatory protein $(n t r C)$ \\
\hline SMc01110 & 15.2 & 9.6 & 1 & DNA-binding protein $(p h r R)$ \\
\hline SMc01140 & 21.2 & 5.8 & 3 & Sigma 54 modulation protein \\
\hline SMc01141 & 16.4 & 6.6 & 3 & Nitrogen regulatory IIa protein $(p t s N)$ \\
\hline SMc01183 & 25.7 & 9.2 & 3 & Transcription regulator LexA repressor \\
\hline SMc01225 & 34.2 & 6.4 & 3 & Transcription regulator not classified regulator \\
\hline SMc01260 & 15.2 & 8.5 & 2 & Transcription regulator not classified regulator \\
\hline SMc01787 & 19.6 & 7.5 & 3 & Transcription regulator not classified regulator \\
\hline SMc01842 & 37.4 & 6.2 & 2 & Transcription regulator methyltransferase \\
\hline SMc01908 & 18.0 & 5.9 & 3 & Transcription regulator not classified regulator \\
\hline $\mathrm{SMc02340}$ & 28.0 & 6.7 & 3 & Transcription regulator not classified regulator \\
\hline SMc02560 & 27.2 & 5.7 & 2 & Transcriptional regulatory protein $(c h v I)$ \\
\hline SMc02584 & 21.5 & 9 & 3 & Transcription regulator global regulatory functions $(a c t R)$ \\
\hline SMc03011 & 13.7 & 9.9 & 3 & Chemotaxis regulator (cheY2) \\
\hline SMc03140 & 27.6 & 7.1 & 2 & Transcription regulator not classified regulator \\
\hline SMc03806 & 12.2 & 7.5 & 3 & Nitrogen regulatory protein PII $(g \ln K)$ \\
\hline SMc03820 & 25.7 & 5.3 & 1 & Transcription regulator not classified regulator \\
\hline SMc04198 & 24.3 & 5.8 & 3 & Phage repressor \\
\hline SMc04234 & 7.4 & 5.8 & 2 & Transcription regulator cold shock-like protein (csp4) \\
\hline SMc04882 & 33.2 & 6.3 & 3 & Transcription regulator not classified regulator \\
\hline
\end{tabular}

${ }^{\mathrm{a}} \mathrm{M}_{\mathrm{P}}=$ molecular mass, $\mathrm{pI}=$ isoelectric point. 
charide synthesis proteins or the various permeases of $\mathrm{ABC}$ transporters) were almost completely absent from the proteins found and alternative strategies will be required to examine these proteins (e.g., sodium dodecyl sulfate [SDS] extraction of membrane preparations followed by 1-D gel electrophoresis and analysis by mass spectrometry). It is doubtful that a 2DGE-compatible non-ionic detergent will be capable of solubilizing, or allowing isolectric focusing of, the most hydrophobic classes of membrane proteins. Several hydrophilic proteins (e.g., the 60-kDa chaperonin, the ATPase alpha chain, and the 30 and 50S ribosomal proteins, S2 and L25) were observed in the membrane preparations, most likely as contaminants from the proteins in the more soluble fraction. None of these hydrophilic proteins have predicted transmembrane domains.

\section{Putative condition-dependent proteins found}

in nodule bacteria.

Of the 439 nodule bacteria proteins analyzed, 170 proteins were identified. Twenty-seven of these proteins were found only in the nodule bacteria samples and are likely to be nodulespecific (Fig 3; Table 5). As expected, the proteins included the abundant nitrogen-fixation proteins NifH, NifD, NifK, FixB, and FixC and the heme biosynthesis protein, coprophyrinogen oxidase (HemF; SMc00180). The presence of several chaperonin or heat shock and stress-related proteins in nodules, including SMc0125, SMb21183, SMb21295, SMc00094 (betaine aldehyde dehydrogenase), and SMc01224 (thioredoxin reductase), together with SodB and KatA, suggests that these proteins play an important role in symbiosis. It is possible that rhizobia may be affected by reactive oxygen species generated as a result of metabolism (e.g., by the high requirement for iron during symbiosis that may generate free radicals) or as a result of reactive oxygen species generated by the host (Santos et al. 2000, 2001) (Fig. 3).

The nodule-expressed transmembrane modification enzyme, SMc02296, is of interest because a homologous protein is implicated in host-pathogen interactions in Yersinia pseudotuberculosis and Vibrio cholerae (Julio et al. 2001) and this may be another example of a gene that is common to pathogenesis and symbiosis (Keen 2000). SMc04135 is a candidate for a nodulespecific ABC-transporter periplasmic binding protein, but the specificity of this transport system is unknown. The presence
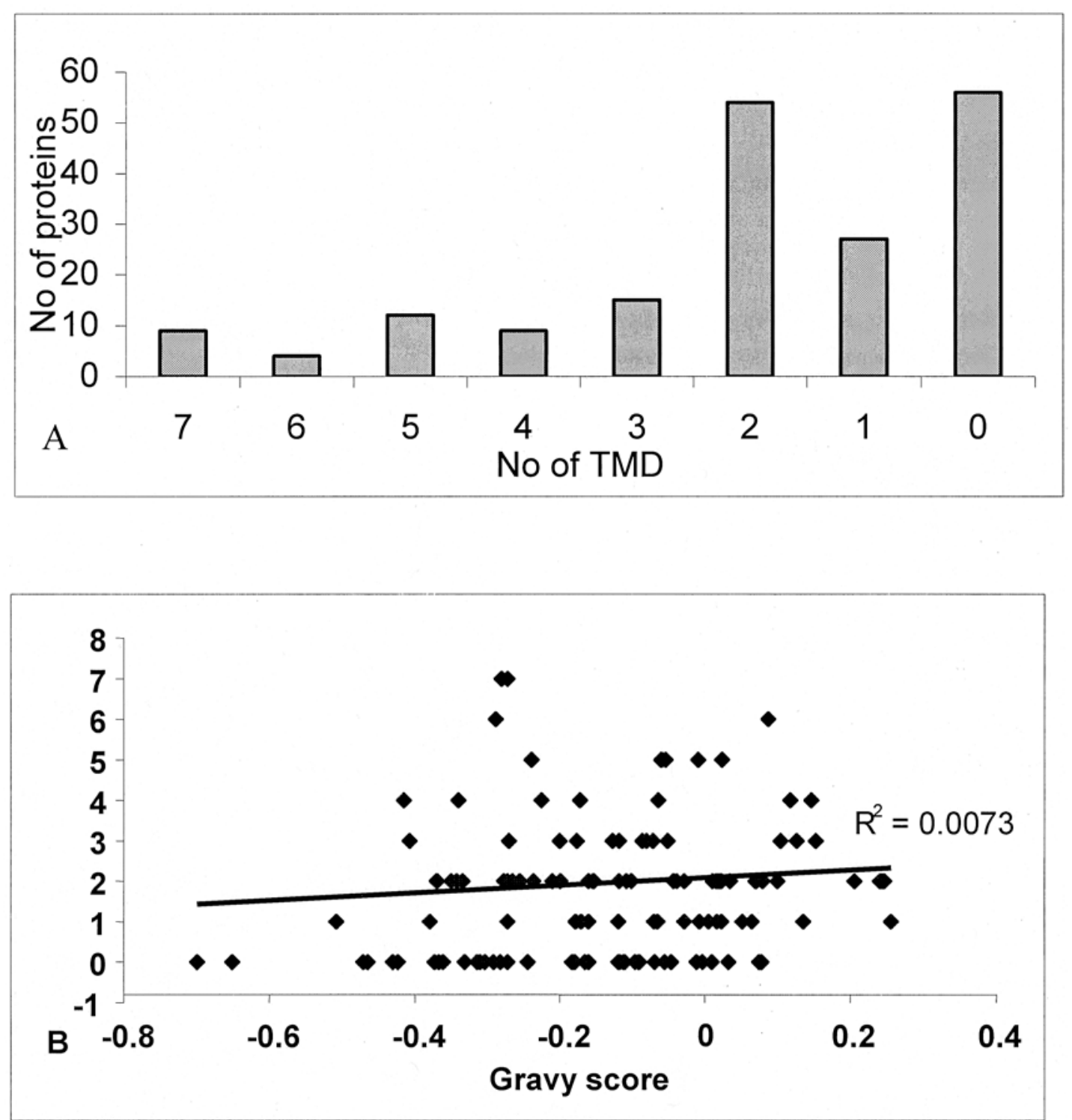

Fig. 4. Analysis of membrane proteins. A, Number of proteins with differing numbers of transmembrane domains (TMDs). Proteins detected in the membrane preparation possessed between zero and seven predicted TMDs. B, No correlation was found between the predicted overall hydrophobicity (Gravy Score) of the proteins in the membrane preparations and the number of predicted TMDs. 
in nodules of GcvT, a protein involved in the oxidative cleavage of glycine into $\mathrm{CO}_{2}, \mathrm{NH}_{3}$, and methylene carbon units, could form an important step in nitrogen metabolism in nodule bacteria, although auxotrophs for Gly synthesis are symbiotically competent (Udvardi and Day 1997). Four hypothetical proteins were found in the nodule bacteria only (Table 5). Several membrane-associated proteins that are expressed in nodules merit investigation (Fig. 3), as do the proteases that are active in nodules, because these play important roles in the outcomes of host-microbe interactions.

The nodule-expressed protein Nex18 (Oke and Long 1999) was found in the nodule bacteria and also under several cultured conditions, and its expression is not nodule specific (Davey and de Bruijn 2000). The gene, nex18, appears on the same operon as $t s p O$, a gene encoding an outer membrane protein involved in stress signaling (Davey and de Bruijn 2000). TspO could not be identified in 2-D gels derived from stationary phase cells or nodule bacteria; however, the ease in identification of Nex18 offers a useful biomarker for expression of this operon and possibly the stress responses that may be mediated through TspO. These results also support the finding that there is an overlap in stress-induced and nodule-occupation regulons (Cabanes et al. 2000; Davey and de Bruijn 2000). TspO regulates NdiA (Davey and de Bruijn 2000) and our data showed that NdiA was found under C-stressed conditions (discussed below). It is possible that TspO also regulates several of the proteins found in this study under symbiotic conditions, and a study of nodule bacteria containing a $\operatorname{tsp} O$ mutation would be of interest. Six other proteins, FumC, PdxJ, ThiC, GabD1, Tig, and AatA, were found in nutrient-stressed and nodule bacteria (Table 6).

\section{Putative condition-dependent proteins found under nutrient-stressed.}

We used a new approach using the mass spectrometer to assess whether a protein was "induced" or "repressed" following nutrient deprivation. Following "spot-to-spot" comparisons of control and treatment gels, proteins were defined as induced or repressed when detectable peptide peaks were present in one sampling point (e.g., on the control gel) but not in the corresponding sampling point on the (e.g., test) gel. We did this because, in several cases, two proteins (A and B) occurred in what appeared to be one protein spot on the control gel (for example), but only protein $B$ at the same coordinate on the test gel (i.e., none of the peptides of protein A were detectable on the test gel). In this case, gel imaging analysis would conclude erroneously that there was a down-regulation in the intensity of the spot between the two gels. In addition, in cases where a spot appears on one gel and not another, it is possible that a posttranslational modification that imparts a charge change may have moved the protein from one location on one gel (e.g., control gel) to another location (on the test gel). The two protein spots in this case could be erroneously assessed as "novel" or repressed whereas, if whole gel analysis was conducted, it is likely that both the modified and nonmodified forms could be identified. Therefore, given that a 2-D gel array of proteins is likely to contain many protein spots where $>1$ protein is present and that the movement of certain proteins on gels is common, a spot-to-spot comparison of the entire contents of control and test gels would be a more reliable way to distinguish between the "presence" and "absence" of a particular protein. Nevertheless, although traditional spot quantification has many drawbacks, it still is required to determine the level of up or down regulation of the majority of proteins that do not move.

Using the spot-to-spot approach, we identified a total of 221 proteins resulting from 119 genes from cells grown in morpholinepropanesulfonic acid (MOPS) medium (cobalt-limited, control) and in MOPS medium where $\mathrm{P}$ or $\mathrm{C}$ was further limited. The cells grown in MOPS grew exponentially to mid-log phase before growth slowed and the cells entered stationary phase. In MOPS medium where either $\mathrm{P}$ or $\mathrm{C}$ was limited, the cells entered stationary phase earlier than in the control and the final optical

Table 5. Putative bacteroid-specific proteins that were not detected under other conditions ${ }^{\mathrm{a}}$

\begin{tabular}{|c|c|c|c|c|}
\hline Gene ID & pI & $\mathbf{M}_{\mathbf{P}}(\mathbf{k D a})$ & Confidence score & Assigned function \\
\hline $\mathrm{SMa} 0125$ & 5.6 & 12 & 2 & GroES3 Chaperonin \\
\hline SMa0817 & 6.8 & 53 & 3 & FixC Oxidoreductase \\
\hline SMa0819 & 6.8 & 40 & 3 & FixB electron transfer flavoprotein alpha chain \\
\hline SMa0825 & 5.6 & 32 & 3 & NifH nitrogenase Fe protein \\
\hline SMa0827 & 5.6 & 56 & 3 & NifD Nitrogenase Fe-Mo alpha chain \\
\hline SMa0829 & 6.1 & 57 & 3 & NifK nitrogenase Fe-Mo beta chain \\
\hline SMb20422 & 5.9 & 37 & 3 & Oxidoreductase \\
\hline SMb21183 & 5 & 71 & 3 & Probable chaperonin, heat shock Hsp90 proteins family HtpG \\
\hline SMb21295 & 5.2 & 18 & 3 & Putative small heat shock protein, hsp20 family \\
\hline SMc00094 & 5.6 & 52 & 3 & $\begin{array}{l}\text { Betaine aldehyde dehydrogenase BadH Oxidoreductase NAD } \\
\text { BetB }\end{array}$ \\
\hline SMc00180 & 6.4 & 34 & 3 & Coproporphyrinogen III oxidase, aerobic HemF \\
\hline SMc00342 & 6.4 & 26 & 2 & Conserved hypothetical protein \\
\hline SMc01119 & 4.9 & 24 & 3 & Hypothetical/global homology \\
\hline SMc01224 & 5.5 & 35 & 3 & Thioredoxin reductase, TrxB \\
\hline SMc01227 & 5.9 & 38 & 3 & Glycerol trinitrate $(\mathrm{gtn})$ reductase NerA \\
\hline $\mathrm{SMc} 01285$ & 4.8 & 38 & 3 & DNA-directed RNA polymerase alpha chain, RpoA \\
\hline SMc01345 & 6.0 & 46 & 3 & Biotin carboxylase, AccC \\
\hline SMc02047 & 5.7 & 39 & 3 & $\begin{array}{l}\text { Aminomethyltransferase (glycine cleavage system } \mathrm{T} \text { protein) } \\
\text { GcvT }\end{array}$ \\
\hline SMc02226 & 4.7 & 16 & 3 & Hypothetical \\
\hline SMc02296 & 5.9 & 60 & 2 & Transmembrane modification enzyme, $\mathrm{HsdM}^{\mathrm{b}}$ \\
\hline SMc02465 & 5.9 & 66 & 3 & Succinate dehydrogenase flavoprotein subunit, SdhA \\
\hline SMc02695 & 5.3 & 41 & 2 & GTP-binding protein \\
\hline SMc02819 & 5.6 & 28 & 1 & Ribonuclease \\
\hline SMc03163 & 5.4 & 43 & 3 & Xylose isomerase, $\mathrm{XylA}$ \\
\hline SMc03251 & 4.5 & 24 & 3 & Hypothetical \\
\hline SMc04135 & 5.3 & 41 & 3 & $\mathrm{ABC}$ transporter periplasmic binding protein \\
\hline SMc04405 & 4.9 & 39 & 3 & 3-isopropylmalate dehydrogenase \\
\hline
\end{tabular}

${ }^{\mathrm{a}} \mathrm{M}_{\mathrm{P}}=$ molecular mass, $\mathrm{pI}=$ isoelectric point.

$\mathrm{b}$ This protein is implicated in host pathogenesis (Julio et al. 2001) 
density (OD) was diminished. We identified 35 proteins that were observed only in these conditions (Table 6; Fig. 3).

\section{Proteins affected by $\mathbf{P}$ limitation.}

Nine proteins were induced (Table 6) under P nutrient stress, including the pSymA proteins SMa1809 (a nonheme haloperoxidase), SMa0065 (putative GntR-family transcriptional regulator) and SMa1821 (hypothetical), the pSymB proteins SMb20806 (hypothetical) and SMb21003 (putative oxidoreductase), and the chromosomal proteins SMc02038 (glycerol dehydrogenase), SMc00145, SMc01518, and SMc01769 (all hypothetical). Both MetC and CysD were repressed (Table 6), which is consistent with a reduction in the synthesis of N-containing compounds under nutrient limitation. Up-regulated proteins included the thiamine biosynthesis proteins (SMb2061620617) and the hypothetical protein, SMc01514. The proximity of SMc01514 (up-regulated) and SMc01518 (induced) in the genome suggests that these genes are part of a new, important stress-induced operon. Other MOPS medium-specific proteins included SMb21097 (periplasmic solute binding protein precursor), SMc03820 (transcriptional regulator), and SMc04296 (cell division protein, FtsZ2).

\section{Proteins affected by $\mathbf{C}$ limitation or by $\mathbf{P}$ and $\mathbf{C}$ limitation.}

Four proteins appear to be induced under C-limitation conditions: SMb20227 (the nutrient-deprivation-induced protein, NdiA-1), SMc00371 (hypothetical), SMc01862 (involved in cell wall synthesis), and SMc02689 (aldehyde dehydrogenase), which is involved in the degradation of $\mathrm{C}$ compounds. Two proteins were repressed: SMc03800 (hypothetical) and SMc00682 (HipO). One protein, SMc04245 (ZnuA), was repressed under both $\mathrm{C}$ and $\mathrm{P}$ limitation but present only in MOPS medium. As with many other periplasmic proteins, this high-affinity zinc-binding protein occurred as three charge iso-

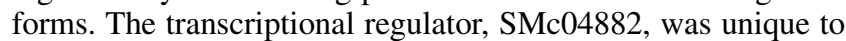
MOPS medium cells but down regulated under $\mathrm{C}$ limitation conditions and could play a role in stress adaptation networks. Several proteins were found both under nutrient limitation and in nodule bacteria (Fig. 3).

A large number of the putative nutrient-stress-specific proteins were predicted to be located in the membrane or periplasmic space (Fig. 3), suggesting a direct role of the protein in modulating or coping with the particular stress. The proteins identified in nutrient-stress conditions that appear to be differentially regulated include several transcriptional regulators (SMa0065, SMc03820, and SMc04882) that may play key regulatory roles during nutrient limitation. There was evidence of a two-tiered response to nutrient limitation with proteins such as the high-affinity zinc-uptake ABC transporter (SMc04245) being induced in MOPS medium but repressed by further limitation of either $\mathrm{C}$ or $\mathrm{P}$. The expression pattern of $\mathrm{SMc} 04245$ would be consistent with its being able to transport Co because MOPS medium is Co deficient. Alternatively, this regulation pattern could be a secondary response to Co-deficiency in the MOPS medium.

The nonheme haloperoxidase (SMa1809) that was induced under P limitation could be involved in protection reactions or possibly in the production of low molecular weight metabolites such as antibiotics that are made by bacteria under stress conditions (Roddam et al. 2002; Weisner et al. 1986). The putative amino acid-binding protein SMb21097, the aminopeptidase (SMc00382), aldehyde dehydrogenase (SMc02689), malonic semialdehyde oxidative decarboxylase (SMc00781), and RhbB (SMa2402) were up regulated, induced, or specific to nutrientstress conditions. Some of these proteins (SMb21097 and SMc00382) could be involved in scavenging nutrients from autolyzed cells in stationary phase or procuring nutrients from the environment. Consistent with this theme, RhbB is involved in rhizobactin siderophore biosynthesis (Lynch et al. 2001) and SMc02689 and SMc00781 are involved in degradation reactions. The data suggested that the free amino acid pool was low under nutrient stress because two genes involved in amino acid biosynthesis, CysD and MetC, were down regulated or repressed. However, CysD (encoding the small subunit of ATP sulfurylase) also could be involved in the addition of modifications to exported molecules such as Nod factors (Schwedock et al. 1994; Shen et al. 2002). The enhanced synthesis of polysaccharides and glycerol in Rhizobium spp. when entering stationary phase or under stress is well recognized, and this could explain the presence of SMc01795 and SMc02038. Our data showed that proteins involved in thiamine biosynthesis are induced during both nodule formation and nutrient stress.

Several genes in $S$. meliloti are known to be up regulated (alkaline phosphatase; the high-affinity inorganic phosphate uptake, PhoCDET; genes involved in the biosynthesis of exopolysaccharide II; and genes involved in the biosynthesis of phosphorous-free membranes) or down regulated (the lowaffinity inorganic phosphate OrfA-Pit) under limiting P (Bardin et al. 1996, 1998; Geiger et al. 1999; McDermott 2000). Of these, only PhoD was detected using a proteomic approach. Contrary to expectations, PhoD was constitutive under a range of conditions in S. meliloti strain 1021 but was further up regulated by $\mathrm{P}$ limitation. In contrast, $\mathrm{PhoD}$ was not constitutive in S. meliloti strain 2011, which was derived from the same parental strain as 1021, and this constitutes an important difference between the two strains. Nevertheless, the approach used here has identified new genes that are potentially regulated by the limitation of $\mathrm{P}$; therefore, this study makes an important contribution to a more holistic definition of a phosphate regulon.

Using a gene-tagging approach, Milcamps and associates (1998) recognized 33 genes that were expressed in response to $\mathrm{C}$ or $\mathrm{N}$ nutrient deprivation. A comparison of the results shows that there is little overlap in the genes recognized in our and their study. Only NdiA is common to the two data sets. In addition, we found the transmembrane efflux protein (SMb20346) in stationary phase cells grown in TA medium, whereas Milcamps and associates (1998) found that this gene was induced under $\mathrm{C}$ limitation conditions. These results show the advantages of using two different approaches. Nevertheless, the unexpected pleiotropic effects of mutagenesis should not be overlooked (Guerreiro et al. 2000) and further work is required to determine the full extent of the responses of rhizobia to nutrient and other stresses.

\section{Posttranslational modifications and protein isoforms.}

The full extent of posttranslational modification of proteins in bacteria is unknown. Many predicted proteins annotated from the genome were implied to possess N-terminal signal sequences using the SignalP program. When the (full-length) matched proteins were examined using peptide mass fingerprinting, the lack of peptides matching to the predicted $\mathrm{N}$-terminus of the (mature) protein, together with shifts in the $\mathrm{pI}$ and $\mathrm{M}_{\mathrm{r}}$, implied that $\mathrm{N}$-terminal processing was occurring in these proteins. It would be useful to use bioinformatics to predict the $\mathrm{pI}$ and $\mathrm{M}_{\mathrm{P}}$ of the mature $\mathrm{N}$-terminally processed proteins and to use this information to make peptide mass fingerprint matches.

A relatively large number of protein charge isoforms that affected gel mobility were recognized in S. meliloti. Data presented above already suggested that some of these were artifacts resulting from proteolytic cleavage of $S$. meliloti proteins in the nodule bacteria preparations and also by the formation of homogeneous mulitmers. In other instances, we could confirm the existence of some posttranslational modifications using peptide mass fingerprinting data. The covalent addition of UMP to Tyr51 in both the 
GlnK or GlnB products was demonstrated (Fig. 5). Addition of UMP to both proteins led to a 306-mass-unit shift of the peptide carrying the UMP modification as well as a pI shift of the modified proteins to a more acidic position, as would be predicted. Therefore, the relative amount of UMP-GlnB or UMP-GlnK compared with the nonmodified forms could be inferred directly. This is a convenient way to determine the state of N-metabolism in the cell, considering the importance that these proteins play in this process. A novel finding was that GlnB occurred as three distinct isoforms and GlnK as four distinct isoforms (Fig. 5) that varied in $\mathrm{pI}$ but appeared to have the same $\mathrm{M}_{\mathrm{r}}$. Although some of these isoforms are due to the presence and absence of UMP, this modification could not explain the presence of all the isoforms found.
One protein that occurred in distinct isoforms that varied in both $\mathrm{pI}$ and $\mathrm{M}_{\mathrm{r}}$ was the nodule-expressed protein, Nex18 (Oke and Long 1999). The Nex18 protein (SMa1077) appeared between 19 and $11 \mathrm{kDa}$ over a pI range ( $\mathrm{pH} 4.6$ to 4.9). Although good peptide coverage was obtained for this protein, the data gave no clues as to why Nex18 appeared at different positions on the gel. Another protein that occurred in multiple locations on gels was Smc02111, which possessed multiple charge isoforms that appeared to be of similar $\mathrm{M}_{\mathrm{r}}$.

\section{An overall perspective: what does this approach tell us about the biology of $S$. meliloti?}

One striking feature of the proteomes of cultured cells grown in either B3 or TA media is the overall stability of the pro-

Table 6. Protein detected only in nutrient-stressed MOPS medium and not under other conditions

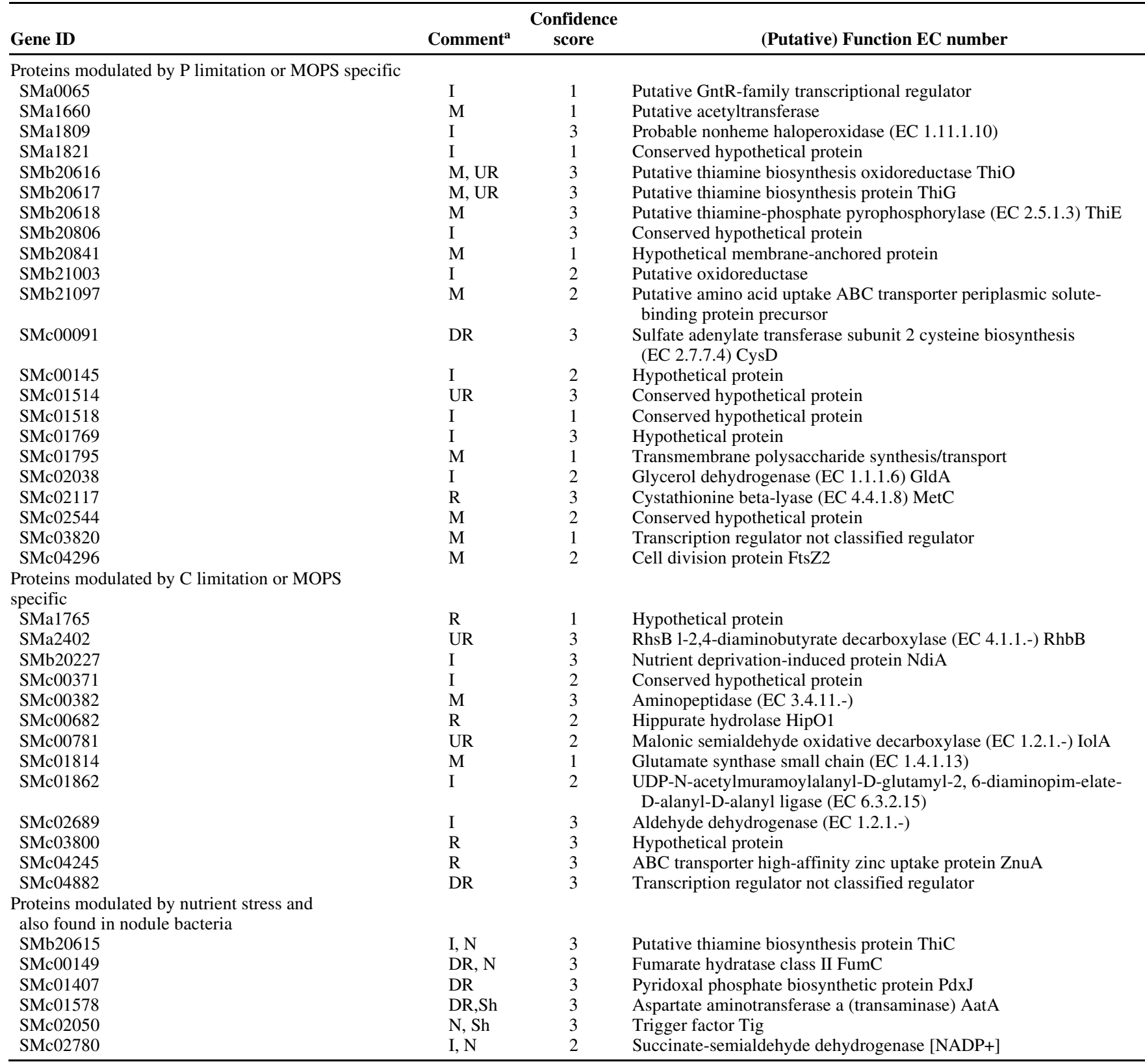

${ }^{\mathrm{a}} \mathrm{I}=$ induced: peptides occurring in these proteins were found only under severe nutrient limitation conditions (MOPS minus P or C) and not the control (MOPS) conditions. This was deduced after direct comparison of the mass spectra of the corresponding spots on control (MOPS) and MOPS nutrient limited. M = MOPS-specific protein not found in any other condition tested; UR = up-regulated protein occurring in control but more than twofold induction in MOPS medium that was nutrient limited; $\mathrm{DR}=$ down-regulated protein to a level of $50 \%$ of that of the control; $\mathrm{R}=$ repressed: peptides occurring in these proteins were found in the MOPS control conditions but not under further nutrient limitation; $\mathrm{N}=$ found in nodule bacteria; and Sh = found in Sherwood medium-grown cells. 
teome patterns regardless of the phase of growth. It appears that the cells maintain a molecular homeostasis over a wide range of conditions in batch culture even though nutrient and oxygen availability would vary widely as the cells changed growth phase. Given this, a wide range of conditions, preferably using chemostat cultures, would be required to tease apart regulatory networks that are influenced by specific environmental changes. Ideally, both short-term and longer-term responses to environmental changes should be studied. To fully assess the extent of regulatory networks in S. meliloti, simultaneous proteomic, transcriptomic, and mutagenic methodologies should be employed on the same samples.

Several proteins involved in key steps of the regulation of $\mathrm{N}$ metabolism were identified, including GlnB and GlnK (PII proteins), GlnA, GlnII, and NtrC. We unequivocally identified the UMP-modified and nonmodified forms of both PII proteins in S. meliloti. Contrary to previous reports (Natera et al. 2000), we conclude that all seven isoforms of $\mathrm{GlnB}$ and $\mathrm{GlnK}$ were absent in nodule bacteria. We previously had concluded that some PII protein isoforms of GlnB were present in the nodule due to a nodule bacteria protein migrating to the same location as GlnB does in cultured cells. Our current analysis shows that this protein is not GlnB in the nodule bacteria samples. This result further emphasizes that both control and test protein spots should be analyzed before conclusions are drawn, because spots containing the same coordinates on two gels are not always the same. The absence of both GlnB and GlnK from nodule bacteria suggests that these proteins may play a role in symbiosis prior to bacteroid formation, because GlnK mutants are symbiotically defective (Arcondeguy et al. 1997). The regulation of the activity of GlnA also is controlled by posttranslational modification (Arcondeguy et al. 1996). Multiple charge isoforms of both GlnA and GlnII also were found; however, from the spectra, we were not able to identify any of the peptide modifications responsible. GlnII was present in crude nodule bacteria, bacteroids, and culture-grown cells, whereas GlnA was found in cultured bacteria and crude nodule preparations.

From an analysis of the pathways present in nodule bacteria and cultured cells, the following conclusions can be drawn. First, it is clear that TCA intermediates are highly abundant in nodule bacteria cells, as are the steps in gluconeogenesis that convert phosphoenolpyruvate (PEP) to $\beta$-D-fructose 1,6 diphosphate. Although PEP carboxykinase (PckA) was easily detected in cultured bacteria under different conditions, this protein was not detected in nodule bacteria. The results of Osteras and associates (1997) support these observations. Therefore, our data support the existence of an alternative pathway for linking TCA intermediates with gluconeogenesis. In addition, current models indicate that sugars are not utilized by bacteroids and that amino acids are likely to be important nitrogen sources for bacteroids (Udvardi and Day 1997). Our data supports this hypothesis. No protein involved in sugar transport or the early steps of glycolysis was detected in nodule bacteria, although they clearly were present in cultured bacteria. Furthermore, several transporters for amino compounds (leucine [SMc01946], amino acids [SMc02118, SMc00140, and Smb20428], oligopeptides [SMb21196], and glycine betaine [SMc04439]) were present in nodule bacteria (Fig. 3). In addition, multiple transporters for iron (FbpA and SitA) and phosphate (PhoD and SMc02146) also were present, highlighting their importance in the physiology and biochemistry of nodule bacteria (Fig. 3) and indicating that double mutants may be needed to fully assess the role of these micronutrients in nodule biology. Aspartate aminotransferase (AatA; SMc01578) was found in nodule bacteria and also under $\mathrm{P}$ limitation in both Sherwood and MOPS medium (Fig. 3). AatA is an important enzyme in aspartate catabolism and biosynthesis and forms an important link between $\mathrm{C}$ and $\mathrm{N}$ metabolism.
The pathways branched chain amino acid synthesis was strongly expressed in both nodule bacteria and cultured cells. The identification of these enzymes is of interest because mutations in the gene encoding IlvC (Lopez et al. 2001), but not other steps in this pathway, have adverse effects upon establishing symbiosis. The knowledge of the coordinates of each enzyme in this pathway will help to unravel the pleiotropic effects of $i l v C$ mutations in strain 1021. We also have identified enzymes involved in the biosynthesis and degradation of other amino acids which will be important to elucidate the effects of amino acid auxotrophy on symbiosis. Enzymes involved in the production of indole acetic acid were active in nodule bacteria and cultured cells, although there is no defined role for bacterial IAA in symbiosis.

This article lays the foundation for future studies of the biology and metabolism of $S$. meliloti and addresses some of the unresolved issues surrounding metabolism in nodule bacteria and cells under nutrient stress. By using "global" approaches to gene expression, a fuller understanding of the remarkable ability of $S$. meliloti to occupy a wide range of microniches will be obtained.

\section{MATERIALS AND METHODS}

\section{Microbiological material and techniques.}

The $S$. meliloti 1021 cells (Galibert et al. 2001) used to generate the "baseline proteome output" were grown at $28^{\circ} \mathrm{C}$ in defined minimal BIII medium (Dazzo 1982) or rich TA medium (Chen et al. 2000), to early-exponential, late-exponential, or stationary phase at $200 \mathrm{rpm}$.

For the nutrient limitation experiments, all cleaned glassware was further washed and autoclaved in ultrapure water to remove trace phosphonates (residual detergent) that could be used as a source of P. The water was discarded prior to adding medium components. As controls for the nutrient limited experiments, cultures were grown in Bardin MOPS medium ((Bardin et al. 1996); limited for cobalt; T. Finan personal communication) to stationary phase (OD at $600 \mathrm{~nm}=0.7$ to 0.8 ) or Sherwood medium (Sherwood 1970) to late log phase. Cultures that were limited for inorganic phosphate $(\mathrm{Pi})$ were grown in Bardin MOPS medium before transfer to MOPS medium modified to contain $9 \mu \mathrm{M} \mathrm{P}$ as $\mathrm{K}_{2} \mathrm{HPO}_{4} / \mathrm{KH}_{2} \mathrm{PO}_{4}$ or Sherwood medium modified to contain $20 \mu \mathrm{M}$ P. For carbon-limited cultures, strain 1021 was grown in MOPS medium before transfer to MOPS modified to contain $1.85 \mathrm{mM}$ succinate. The MOPS medium cultures were grown to stationary phase and harvested at the same time as control cultures.

\section{Nodule bacteria preparations and plant growth.}

Strain 1021 was used to inoculate either M. alba (Natera et al. 2000) or M. truncatula seedlings and grown until nitrogenfixing nodules were obtained. $M$. truncatula seedlings were grown in aeroponic units at INRA in Toulouse (Journet et al. 1994). Bacteroids were isolated from $M$. alba nodules as previously described (Day et al. 1989; Natera et al. 2000). Crude nodule bacterial preparations were obtained from $4 \mathrm{~g}$ of crushed $M$. truncatula nodules using differential centrifugation to obtain a crude "nodule bacteria" preparation, defined here as pooled data from bacteroids and nodule bacteria. Several gels were run from each preparation of bacteroids or crude nodule bacteria and there was good congruency between the protein array patterns obtained for each sample.

\section{Protein extraction and 2-DGE.}

Cells were harvested and samples prepared for 2-DGE using previously described methods (Guerreiro et al. 1997, 1999; Natera et al. 2000) with 18 or $24 \mathrm{~cm}$ of Immobiline Dry Strips, 
pH 4 to 7, 5 to 8, or 6 to 11 (Amersham Pharmacia Biotech, Uppsala, Sweden). Total protein (350 to $1,000 \mathrm{mg}$ ) was cup loaded at the anodic end. For the second dimension, SDS-polyacrylamide gel electrophoresis was used with a Multiphor II electrophoresis system and precast gels with 12 to $14 \%$ acryla- mide gradients (Amersham Pharmacia Biotech). Image analysis and quantification was as previously described (Chen et al. 2000), with up regulation defined as more than twofold greater than controls and down regulation defined as less than $50 \%$ of control levels. All major soluble and membrane protein species

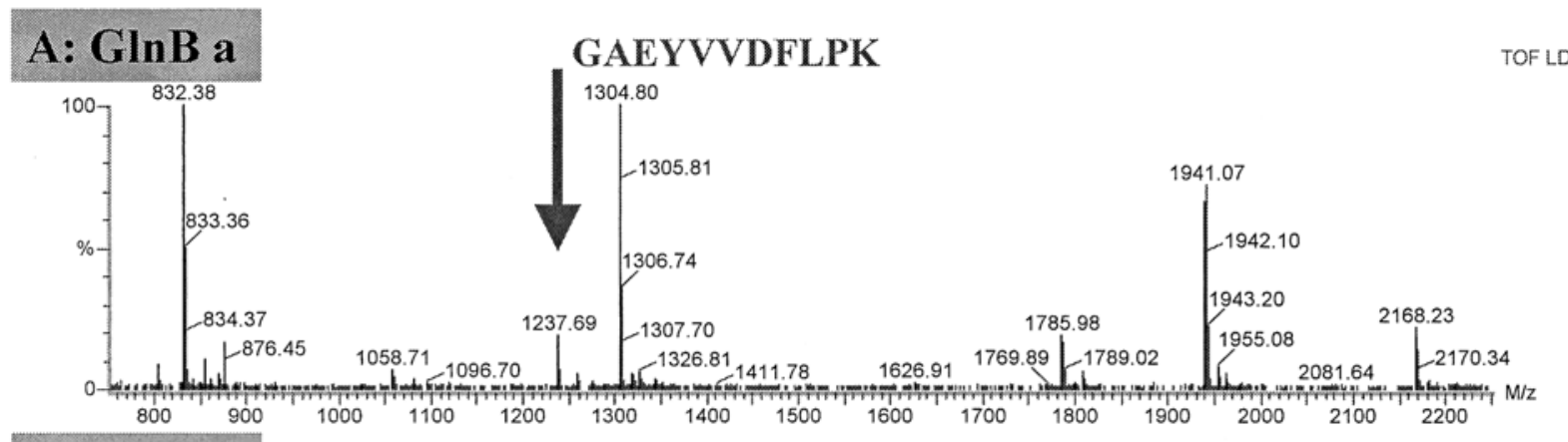

\section{B: GInB c}

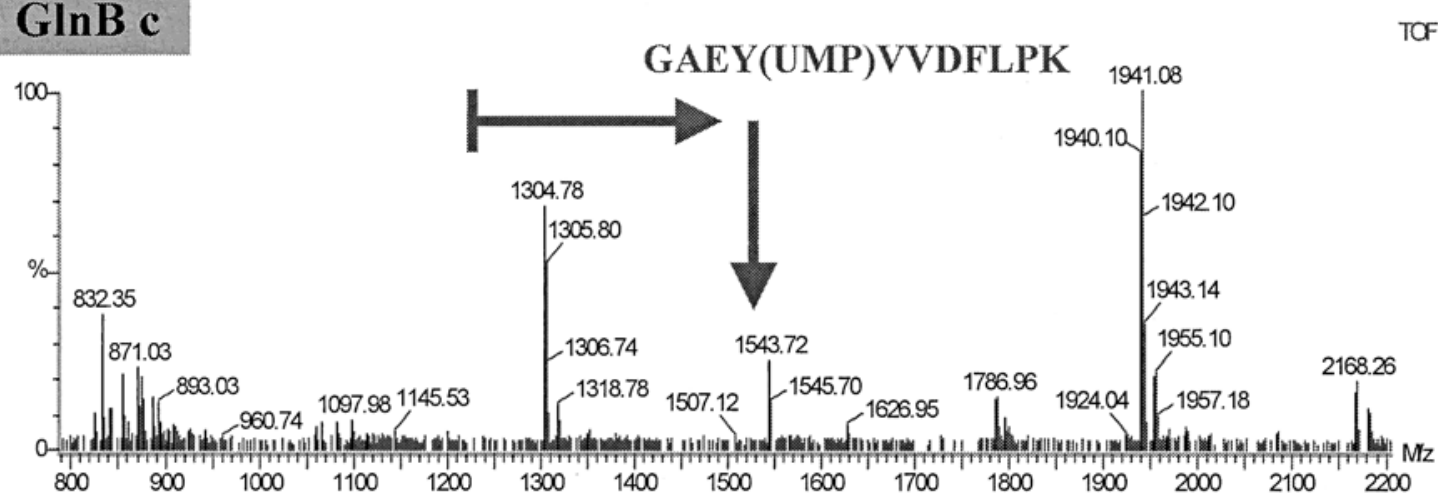

\section{C: GInK a}

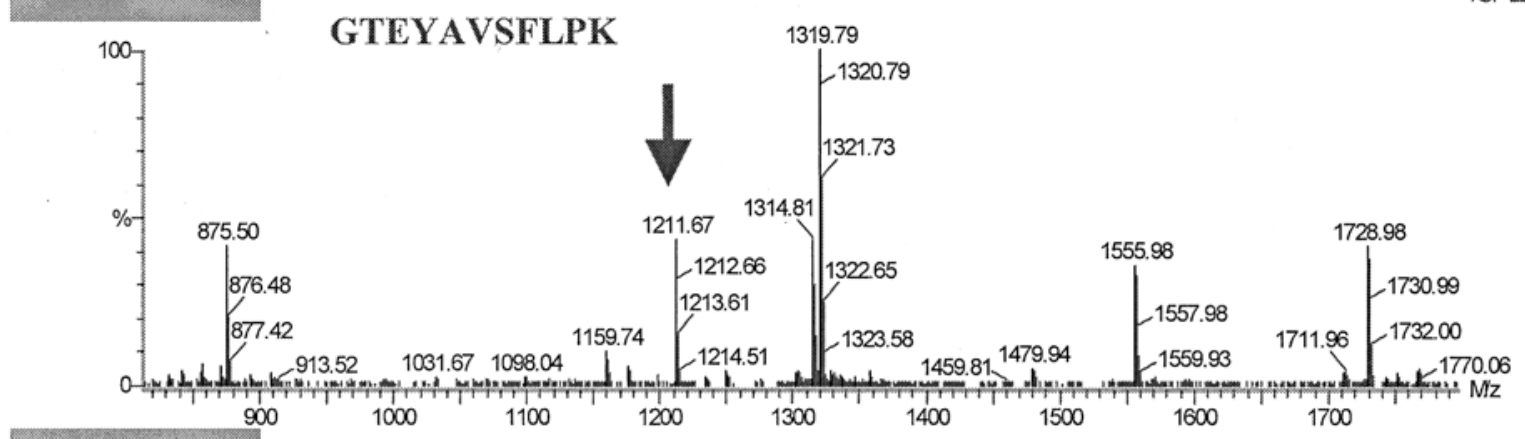

\section{D: GInK c}

CFLD+
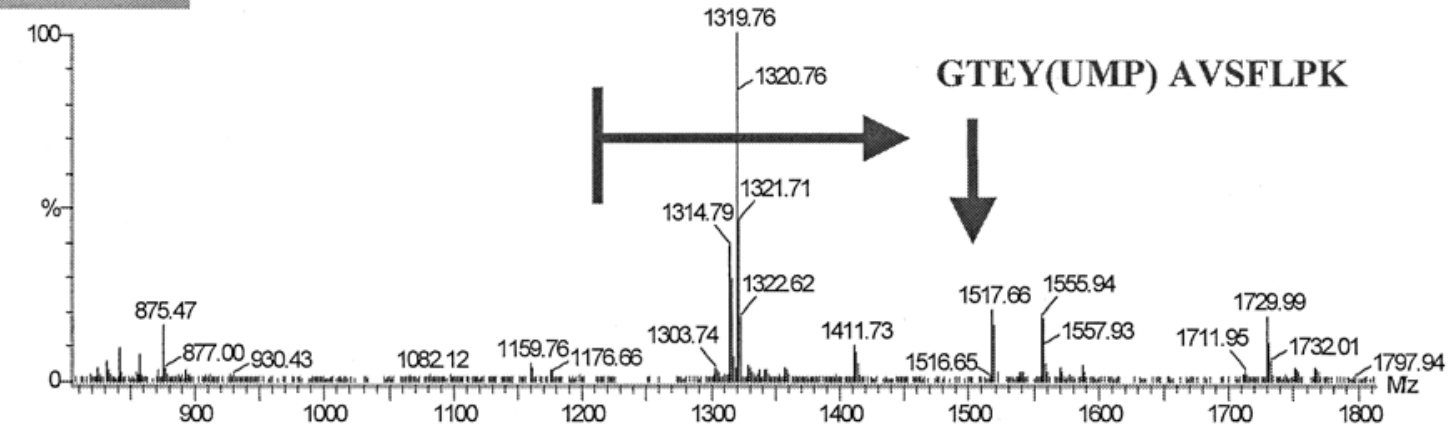

Fig. 5. Modification of PII by UMP. A and B, GlnB was detected in three distinct protein spots (a, b, and c); A, GlnBa and $\mathbf{B}$, GlnBc products. The GlnBc product is more acidic and the loss of a peptide peak at 1,237.69 (corresponding to amino acids 48 to 58) was compensated by the appearance of a peak 306 mass units larger at 1,543.72 in product c but not b or a. Similarly, GlnK was represented by four distinct protein spots (a through d). C, GlnKa and D, GlnKc. In products $\mathrm{c}$ and d, the loss of the peak at 1,211.67 (corresponding to the mass of the amino acids 48 to 58 of the GlnK product) was compensated by the appearance of a peak 306 mass units larger at 1,517.66. In both cases, the 306-mass-unit shifts corresponded to the addition of UMP to tyrosine at position 51 . 
from TA- and B3-grown cells were picked from over 20 gels that collectively covered the $\mathrm{pH}$ range from 4 to 10 with a minimum of least two replicates of each gel and several preparations of cells being run and analyzed. Proteins from nodule bacteria, all nutrient-stress cells, and Sherwood medium-grown cells were arrayed on gels of $\mathrm{pH} 4$ to 7 only.

\section{Preparation of membrane proteins.}

Membrane proteins were isolated using the $\mathrm{Na}$ carbonate precipitation method (Nouwens et al. 2000) starting with a freeze-dried sample of strain 1021 (40 mg) grown in TA medium. The pelleted membrane particles were solubilized in $2 \%$ (wt/vol) ASB14 (Calbiochem, La Jolla, CA, U.S.A.), $2 \mathrm{mM}$ tributylphosphene, $7 \mathrm{M}$ urea, $2 \mathrm{M}$ thiourea, and $0.5 \%$ (wt/vol) carrier ampholytes ( $\mathrm{pH} 3$ to 10 ) and $0.025 \%$ (wt/vol) bromophenol blue. After brief vortexing, the sample was centrifuged at $20,000 \times g$ for $10 \mathrm{~min}$ at room temperature to remove insoluble materials, then subjected to 2-DGE.

We also used an alternative SDS-based method for membrane protein solubilization, where the membrane fraction was solubilized in $2 \mathrm{ml}$ of $4 \%$ SDS solubilization buffer $(100 \mathrm{mM}$ Tris- $\mathrm{HCl}, \mathrm{pH} 8.8,4 \% \mathrm{SDS}$, and $5 \mathrm{mM}$ dithiothreitol [DTT]) and boiled for $5 \mathrm{~min}$. A 10-fold excess of prechilled acetone was added for at least $1 \mathrm{~h}$ at $-20^{\circ} \mathrm{C}$ prior to centrifugation for 5 $\min$ at $12,000 \times g$ at $4^{\circ} \mathrm{C}$. The remaining pellet was lyophilized and then solubilized in $40 \mu \mathrm{l}$ of $0.5 \%$ SDS solubilization buffer (100 mM Tris-HCl, pH 8.8, 0.5\% SDS, $5 \mathrm{mM}$ DTT) for $5 \mathrm{~min}$. The solution was diluted with $150 \mu \mathrm{l}$ of 2 -D solubilization buffer (50 mM Tris- $\mathrm{HCl}$, pH 8.8, $7 \mathrm{M}$ urea, $2 \mathrm{M}$ thiourea, $4 \%$ CHAPS, $5 \mathrm{mM}$ DTT, $0.5 \%$ Triton X-100), agitated using an ultrasonic water bath (Elma Transonic 460; John Morris Scientific, Willoughby, NSW, Australia) for $20 \mathrm{~min}$ with 30 to $60 \mathrm{~s}$ of vortex mixing after each 10 -s pulse, and then centrifuged for $5 \mathrm{~min}$ at $12,000 \times g$ at room temperature.

\section{Protein analysis by PMF.}

Protein spots were excised from Colloidal Coomassie stained gels (Mathesius et al. 2001), placed in a heat-resistant 96-well tray (Nalge Nunc International), and subjected to ingel tryptic digestion and clean up before depositing the digested sample onto a target grid (Mathesius et al. 2001). Mass spectra were generated using a Micromass TofSpec2E (matrix-assisted laser desorption/ionization time-of-flight mass spectrometry [MALDI-TOF MS]; Micromass, Manchester, U.K.) equipped with a 337-nm nitrogen laser. All spectra were obtained in reflectron or delayed extraction mode, averaging 256 laser shots per sample. Two-point internal calibration of spectra was achieved using internal porcine trypsin autolysis peptides (842.5 and $2211.10[\mathrm{M}+\mathrm{H}]^{+}$ions). Lists of single charged peaks corresponding to the mass of generated tryptic peptides were used to search a translated version of the $S$. meliloti genome (Galibert et al. 2001). With proteins that yielded good spectra but failed to be matched to an existing $S$. meliloti gene, we developed a computer program that translated all potential coding sequence of the $S$. meliloti genome. This process was done to ensure that no potential reading frame was overlooked due to incomplete gene prediction or annotation. For each of the six reading frames, translation for the first potential protein sequence starts at the first possible prokaryotic start codon (NTG or ATN) and continues to the first possible stop codon (TAA, TAG, TGA). The next potential protein starts at the first potential start codon following the stop. Only reading frames of 20 aa or longer were considered. In addition, for bacteria isolated from root nodules, each unassigned spectrum was run against the $M$. truncatula database to determine if plant proteins were present in the preparation.
PMF matches were done using MassLynx software (version 3.4; Micromass; Waters Corp., Milford, MA, U.S.A.). Matching was done using the criteria outlined previously (Weiller et al. 2001). Briefly, proteins were given a confidence score of 3 when all four of the following criteria were met: i) when a minimum of four peptides matched within an accuracy of 100 ppm to the theoretical mass of the peptide without the requirement of any allowed peptide modification (e.g., partial cleavage, oxidation of methionine, or cysteine-alkylation or -acrylamide adducts), ii) when the matched peptides collectively composed $>30 \%$ of the entire protein, iii) when there was good congruence between the predicted $\mathrm{M}_{\mathrm{P}}$ and $\mathrm{pI}$ and that measured from the gel, and iv) when a clearly differential MOSWE score was obtained compared to other possible "matches." With small proteins $(<15 \mathrm{kDa})$, three precisely matching, nonmodified, peptides were permitted, but higher percent coverage was demanded $(>40 \%)$. With large proteins $(>60 \mathrm{kDa})$, lower percent coverage was allowed $(>20 \%)$, but the number of matching nonmodified peptides required to make a match was increased to a minimum of 6 . A confidence score of 2 was recorded when one of the criteria was not satisfied but the other matching criteria were satisfied. A confidence score of 1 was recorded when one or more of the criteria were not met but the other criteria were satisfied. The relative proportions of proteins that scored 3, 2, or 1 were 71,20 , and $9 \%$, respectively.

Computer-assisted matching programs often assign an incorrect match. Therefore, each of the 2,596 samples was assessed manually and used as a basis for the establishment of an automatic scoring protocol (Weiller et al. 2001). With bacteria, unmodified peptides are more reliable for matching than those chemically modified by oxidation of methionine or modification of cysteine. When a spot matched two nearly identical proteins (e.g., the 60-kDa chaperonins SMa0744 or SMc00913) or identical proteins (e.g., elongation factor Tu; SMc01311 or SMc01326), both matches were recorded. In cases where two different proteins had sufficient homology to be assigned a match, the protein with the highest number of matching peptides and percent coverage was used as the most likely correct match (e.g., the 60-kDa chaperonin SMa0744 compared with $\mathrm{SMb} 21566)$.

\section{ACKNOWLEDGMENTS}

This research has been facilitated by access to the Australian Proteome Analysis Facility established under the Australian Government's Major Research Facilities Program. We thank B. Rolfe for critically evaluating the manuscript and for thoughtful discussions, and P. Haines at the Australian Proteome Analysis Facility for MALDI-TOF analysis.

\section{LITERATURE CITED}

Arcondeguy, T., Huez, I., Fourment, J., and Kahn, D. 1996. Symbiotic nitrogen fixation does not require adenylylation of glutamine synthetase I in Rhizobium meliloti. FEMS (Fed. Eur. Microbiol. Soc.) Lett. 145:33-40.

Arcondeguy, T., Huez, I., Tillard, P., Gangneux, C., Debilly, F., Gojon, A., Truchet, G., and Kahn, D. 1997. The Rhizobium meliloti p-II protein, which controls bacterial nitrogen metabolism, affects alfalfa nodule development. Genes Dev. 11:1194-1206.

Bardin, S., Dan, S., Osteras, M., and Finan, T. M. 1996. A phosphate transport system is required for symbiotic nitrogen fixation by Rhizobium meliloti. J. Bacteriol. 178:4540-4547.

Bardin, S. D., Voegele, R. T., and Finan, T. M. 1998. Phosphate assimilation in Rhizobium (Sinorhizobium) meliloti-identification of a Pitlike gene. J. Bacteriol. 180:4219-4226.

Barnett, M. J., and Long, S. R. 1997. Identification and characterization of a gene on Rhizobium meliloti pSymA, syrB, that negatively affects syrM expression. Mol. Plant-Microbe Interact. 10:550-559.

Barnett, M. J., Fisher, R. F., Jones, T., Komp, C., Abola, P., Barloy-Hubler, F., Bowser, L., Capela, D., Galibert, F., Gouzy, J., Gurjal, M., Hong, A., Huizar, L., Hyman, R. W., Kahn, D., Kahn, M. L., Kalman, S., Keating, 
D. H., Palm, C., Peck, M. C., Surzycki, R., Wells, D. H., Yeh, K. C. Davis, R. W., Federspiel, N. A., and Long, S. R. 2001. Nucleotide sequence and predicted functions of the entire Sinorhizobium meliloti pSymA megaplasmid. Proc. Natl. Acad. Sci. U.S.A. 98:9883-9888.

Branny, P., Pearson, J. P., Pesci, E. C., Kohler, T., Iglewski, B.H., and Van Delden, C. 2001. Inhibition of quorum sensing by a Pseudomonas aeruginosa dksA homologue. J. Bacteriol. 183:1531-1539.

Brown, L., Gentry, D., Elliott, T., and Cashel, M. 2002. DksA affects ppGpp induction of RpoS at a translational level. J. Bacteriol. 184:4455-4465.

Cabanes, D., Boistard, P., and Batut, J. 2000. Identification of Sinorhizobium meliloti genes regulated during symbiosis. J. Bacteriol. 182:3632-3637.

Capela, D., Barloy-Hubler, F., Gouzy, J., Bothe, G., Ampe, F., Batut, J., Boistard, P., Becker, A., Boutry, M., Cadieu, E., Dreano, S., Gloux, S., Godrie, T., Goffeau, A., Kahn, D., Kiss, E., Lelaure, V., Masuy, D., Pohl, T., Portetelle, D., Puhler, A., Purnelle, B., Ramsperger, U., Renard, C., Thebault, P., and Galibert, F.2001. Analysis of the chromosome sequence of the legume symbiont Sinorhizobium meliloti strain 1021. Proc. Natl. Acad. Sci. U.S.A. 98:9877-9882.

Chen, H. C., Higgins, J., Oresnik, I. J., Hynes, M. F., Natera, S., Djordjevic, M. A., Weinman, J. J., and Rolfe, B. G.2000. Proteome analysis demonstrates complex replicon and luteolin interactions in pSyma-cured derivatives of Sinorhizobium meliloti strain 2011. Electrophoresis 21:3833-3842.

Cheng, H. P., and Walker, G. C. 1998. Succinoglycan production by Rhizobium meliloti is regulated through the ExoS-ChvI two-component regulatory system. J. Bacteriol. 180:20-26.

Colebatch, G., Trevaskis, B., and Udvardi, M. 2002. Symbiotic nitrogen fixation research in the postgenomics era. New Phytol. 153:37-42.

Davey, M. E., and de Bruijn, F. J. 2000. A homologue of the tryptophanrich sensory protein TspO and FixL regulate a novel nutrient deprivation-induced Sinorhizobium meliloti locus. Appl. Environ. Microbiol. 66:5353-5359.

Day, D. A., Price, G. D., and Udvardi, M. K. 1989. Membrane interface of Bradyrhizobium japonicum-Glycine max symbiosis: peribacteroid units from soybean nodules. Aust. J. Plant Physiol 16:69-84.

Finan, T. M., Weidner, S., Wong, K., Buhrmester, J., Chain, P., Vorholter, F. J., Hernandez-Lucas, I., Becker, A., Cowie, A., Gouzy, J., Golding, B., and Puhler, A. 2001. The complete sequence of the 1,683-kb pSymB megaplasmid from the nitrogen fixing symbiont Sinorhizobium meliloti. Proc. Natl. Acad. Sci. U.S.A. 98:9889-9894.

Galibert, F., Finan, T. M., Long, S.R., Puhler, A., Abola, P., Ampe, F., Barloy-Hubler, F., Barnett, M. J., Becker, A., Boistard, P., Bothe, G., Boutry, M., Bowser, L., Buhrmester, J., Cadieu, E., Capela, D., Chain, P., Cowie, A., Davis, R.W., Dreano, S., Federspiel, N. A., Fisher, R. F. Gloux, S., Godrie, T., Goffeau, A., Golding, B., Gouzy, G., Gurjal, M., Hernandez-Lucas, I., Hong, A., Huizar, L., Hyman, R. W., Jones, T., Kahn, D., Kahn, M. L., Kalman, S., Keating, D. H., Kiss, E., Komp, C., Lelaure, V., Masuy, D., Palm, C., Peck, M. C., Pohl, T. M., Portetelle, D., Purnelle, B., Ramsperger, U., Surzycki, R., Thébault, P., Vandenbol, M., Vorhölter, F.-J., Weidner, S., Wells, D. H., Wong, K., Yeh, K.-C., and Batut, J. 2001. The composite genome of the legume symbiont Sinorhizobium meliloti. Science 293:668-672.

Geiger, O., Rohrs, V., Weissenmayer, B., Finan, T. M., and ThomasOates, J. E. 1999. The regulator gene $p h o B$ mediates phosphate stresscontrolled synthesis of the membrane lipid diacylglyceryl-N,N,Ntrimethylhomoserine in Rhizobium (Sinorhizobium) meliloti. Mol. Microbiol. 32:63-73.

Godovac-Zimmerman, J., and Brown, L. R. 2001. Perspectives for mass spectrometry and functional proteomics. Mass Spectrom. Rev. 20:157.

Gottesman, S. 1996. Proteases and their targets in Escherichia coli. Annu. Rev. Genet. 30:465-506

Guerreiro, N., Djordjevic, M. A., and Rolfe, B. G. 1999. Proteome analysis of the model microsymbiont Sinorhizobium meliloti: Isolation and characterisation of novel proteins. Electrophoresis 20:818-825.

Guerreiro, N., Ksenzenko, V. N., Djordjevic, M. A., Ivashina, T. V., and Rolfe, B. G. 2000. Elevated levels of synthesis of over 20 proteins results after mutation of the Rhizobium leguminosarum exopolysaccharide synthesis gene pssA. J. Bacteriol. 182:4521-4532.

Guerreiro, N., Redmond, J. W., Rolfe, B. G., and Djordjevic, M. A. 1997. New Rhizobium leguminosarum flavonoid-induced proteins revealed by proteome analysis of differentially displayed proteins. Mol. PlantMicrobe Interact. 10:506-516.

Hamdan, M., Galvani, M., and Righetti, P. G. 2001. Monitoring 2-D gel induced modifications of proteins by MALDI-TOF mass spectrometry. Mass Spectrom. Rev. 20:121-141.

Hirsch, M., and Elliott, T. 2002. Role of ppGpp in rpoS stationary-phase regulation in Escherichia coli. J. Bacteriol. 184:5077-5087.
Journet, E. P., Pichon, M., Dedieu, A., Debilly, F., Truchet, G., and Barker, D. G. 1994. Rhizobium meliloti Nod factors elicit cell-specific transcription of the ENOD12 gene in transgenic alfalfa. Plant J. 6:241-249.

Julio, S. M., Heithoff, D. M., Provenzano, D., Klose, K. E., Sinsheimer, R. L., Low, D. A., and Mahan, M. J. 2001. DNA adenine methylase is essential for viability and plays a role in the pathogenesis of Yersinia pseudotuberculosis and Vibrio cholerae. Infect. Immun. 69:7610-7615.

Keen, N. T. 2000. A century of plant pathology: A retrospective view on understanding host-parasite interactions. Annu. Rev. Phytopathol 38:31-48.

Loh, J., Stacey, M. G., Sadowsky, M. J., and Stacey, G. 1999. The Bradyrhizobium japonicum nolA gene encodes three functionally distinct proteins. J. Bacteriol. 181:1544-1554.

Lopez, J. C., Grasso, D. H., Frugier, F., Crespi, M. D., and Aguilar, O. M. 2001. Early symbiotic responses induced by Sinorhizobium meliloti ilv $C$ mutants in alfalfa. Mol. Plant-Microbe Interact. 14:55-62

Lynch, D., O’Brien, J., Welch, T., Clarke, P., Cuiv, P. O., Crosa, J. H., and O'Connell, M. 2001. Genetic organization of the region encoding regulation, biosynthesis, and transport of rhizobactin 1021, a siderophore produced by Sinorhizobium meliloti. J. Bacteriol. 183:2576-2585.

Mathesius, U., Keijzers, G., Natera, S. H. A., Weinman, J. J., Djordjevic, M. A., and Rolfe, B. G. 2001. Establishment of a root proteome reference map for the model legume Medicago truncatula using the expressed sequence tag database for peptide mass fingerprinting. Proteomics $1: 1424-1440$

McDermott, T. R. 2000. Pages 529-548 in: Phosphorous Assimilation and Regulation in Rhizobia. E. Tripplet, ed. Horizon Scientific Press, Wymondham, Norfolk, U.K

Milcamps, A., Ragatz, D. M., Lim, P., Berger, K. A., and Debruijn, F. J. 1998. Isolation of carbon- and nitrogen-deprivation-induced loci of $\mathrm{Si}$ norhizobium meliloti 1021 by Tn5-luxAB mutagenesis. Microbiology 144:3205-3218.

Mogull, S. A., Runyen-Janecky, L. J., Hong, M., and Payne, S. M. 2001. $d k s A$ is required for intercellular spread of Shigella flexneri via an RpoS-independent mechanism. Infect. Immun. 69:5742-5751.

Natera, S. H. A., Guerreiro, N., and Djordjevic, M. A. 2000. Proteome analysis of differentially displayed proteins as a tool for the investigation of symbiosis. Mol. Plant-Microbe Interact. 13:995-1009.

Nouwens, A. S., Cordwell, S. J., Larsen, M. R., Molloy, M. P., Gillings, M., Willcox, M. D.P., and Walsh, B. J. 2000. Complementing genomics with proteomics: The membrane subproteome of Pseudomonas aeruginosa PAO1. Electrophoresis 21:3797-3809.

Oke, V., and Long, S. R. 1999. Bacterial genes induced within the nodule during the Rhizobium-legume symbiosis. Mol. Microbiol. 32:837-849.

Oliver, D. J., Nikolau, B., and Wurtele, E. S. 2002. High-throughput protein expression of cDNA products as a tool in functional genomics. Metabol. Eng. 4:98-106.

Osteras, M., Driscoll, B. T., and Finan, T. M. 1997. Increased pyruvate orthophosphate dikinase activity in an alternative gluconeogenic pathway in Rhizobium(Sinorhizobium) meliloti. Microbiology 143:16391648.

Patriarca, E. J., Riccio, A., Colonnaromano, S., Defez, R., and Iaccarino, M. 1994. DNA binding activity of NtrC from Rhizobium grown on different nitrogen sources. FEBS (Fed. Eur. Biochem. Soc.) Lett. 354:89-92.

Perret, X., Freiberg, C., Rosenthal, A., Broughton, W. J., and Fellay, R. 1999. High-resolution transcriptional analysis of the symbiotic plasmid of Rhizobium sp. NGR234. Mol. Microbiol. 32:415-425.

Riley, M. 1998. Systems for categorizing functions of gene products. Curr. Opin. Struct. Biol. 8:388-392.

Roddam, L. F., Lewis-Henderson, W. R., and Djordjevic, M. A. 2002. Two novel chromosomal loci influence cultivar-specific nodulation failure in the interaction between strain ANU794 and subterranean clover cv. Woogenellup. Funct. Plant Biol. 29:473-483.

Santos, R., Herouart, D., Puppo, A., and Touati, D. 2000. Critical protective role of bacterial superoxide dismutase in Rhizobium-legume symbiosis. Mol. Microbiol. 38:750-759.

Santos, R, Herouart, D., Siguad, S., Touati, D., and Puppo, A., 2001. Oxidative burst in alfalfa-Sinorhizobium symbiotic interaction. Mol. Plant-Microbe Interact. 14:86-89.

Schwedock, J. S., Liu, C. X., Leyh, T. S., and Long, S. R. 1994. Rhizobium meliloti NodP and NodQ form a multifunctional sulfate-activating complex requiring GTP for activity. J. Bacteriol. 176:7055-7064.

Selinger, D. W., Cheung, K. J., Mei, R., Johansson, E. M., and Richmond, C. S. 2000. RNA expression analysis using a 30 base pair resolution Escherichia coli genome array. Nature Biotechnol. 18:1262-1268.

Shen, Y. W., Sharma, P., da Silva, F. G., and Ronald, P. 2002. The Xanthomonas oryzae pv. oryzae $\operatorname{rax} P$ and $\operatorname{rax} Q$ genes encode an ATP sulphurylase and adenosine-5' - phosphosulphate kinase that are required 
for AvrXa21 avirulence activity. Mol. Microbiol. 44:37-48.

Sherwood, M. T. 1970. Improved synthetic medium for the growth of Rhizobium. J. Appl. Bacteriol. 33:708-713.

Simpson, A. J. G., Reinach, F. C., Arruda, P., Abreu, F. A., Acencio, M., Alvarenga, R., Alves, L. M. C., Araya, J. E., Baia, G. S., Baptista, C. S., Barros, M. H., Bonaccorsi, E. D., Bordin, S., Bove , J. M., Briones, M. R. S., Bueno, M. R. P., Camargo, A. A., Camargo, L. E. A., Carraro, D. M., Carrer, H., Colauto, N. B., Colombo, C., Costa, F. F., Costa, M. C. R., Costa-Neto, C. M., Coutinho, L. L., Cristofani, M., Dias-Neto, E., Docena, C., El-Dorry, H., Facincani, A. P., Ferreira, A. J. S., Ferreira, V. C. A., Ferro, J. A., Fraga, J. S., Franca, S. C., Franco, M. C., Frohme, M. Furlan, L. R., Garnier, M., Goldman, G. H., Goldman, M. H. S., Gomes, S. L., Gruber, A., Ho, P. L., Hoheisel, J. D., Junqueira, M. L., Kemper, E. L., Kitajima, J. P., Krieger, J. E., Kuramae, E. E., Laigret, F., Lambais, M. R., Leite, L. C. C., Lemos, E. G. M., Lemos, M. V. F., Lopes, S. A., Lopes, C. R., Machado, J. A., Machado, M. A., Madeira, A. M. B. N., Madeira, H. M. F., Marino, C. L., Marques, M. V., Martins, E. A. L., Martins, E. M. F., Matsukuma, A. Y., Menck, C. F. M., Miracca, E. C., Miyaki, C. Y., Monteiro-Vitorello, C. B., Moon, D. H,. Nagai, M. A., Nascimento, A. L. T. O., Netto, L. E. S., Nhani, A., Jr,, Nobrega, F. G., Nunes, L. R., Oliveira, M. A., de Oliveira, M. C., de Oliveira, R. C., Palmieri, D. A., Paris, A., Peixoto, B. R., G. Pereira, G. A., Pereira, H. A., Jr., Pesquero, J. B., Quaggio, R. B., Roberto, P. G., Rodrigues, V., de M. Rosa, A. J., de Rosa, V. E., Jr., de Sa, R. G., Santelli, R. V., Sawasaki, H. E., da Silva, A. C. R., da Silva, A. M., da Silva, F. R., Silva, W. A., Jr., da Silveira, J. F., Silvestri, M. L. Z., Siqueira, W. J., de Souza, A. A., de Souza, A. P., Terenzi, M. F., Truffi, D., Tsai, S. M., Tsuhako, M. H., Vallada, H., Van Sluys, M. A., Verjovski-Almeida, S., Vettore, A. L., Zago, M. A., Zatz, M., Meidanis, J., and Setubal, J. C. B. 2000. The genome sequence of the plant pathogen Xylella fastidiosa. Nature. 406:151-157.

Spaink, H. P. 1996. Regulation of plant morphogenesis by lipo-chitin oligosaccharides. Crit. Rev. Plant Sci. 15:559-582.

Spaink, H. P. 2000. Root nodulation and infection factors produced by rhizobial bacteria. Annu. Rev. Microbiol. 54:257-288

Summers, M. L, Botero, L. M., Busse, S. C., and McDermott, T. R. 2000.
The Sinorhizobium meliloti Lon protease is involved in regulating exopolysaccharide synthesis and is required for nodulation of alfalfa. J. Bacteriol. 182:2551-2558.

Udvardi, M., and Day, D. A. 1997. Metabolic transport across symbiotic membranes of legume nodules. Ann. Rev. Plant Physiol. Plant Mol. Biol. 48:493-523.

Wei, Y., Lee, J. M., Richmond, C., Blattner, F. R.. Rafalski. J. A., and LaRossa, R.A. 2001. High-density microarray-mediated gene expression profiling of Escherichia coli. J. Bacteriol. 183:545-556.

Weiller, G. F., Djordjevic, M. A., Caraux, G., Chen, H. C., and Weinman, J. J. 2001. A specialised proteomic database for comparing matrix-assisted laser desorption/ionization-time of flight mass spectrometry data of tryptic peptides with corresponding sequence database segments. Proteomics 1:1489-1494.

Weisner, W., van Pee, K., and Lingens, F. 1986. Detection of new chloroperoxidase in Pseudomonas pyrrocinia. FEBS (Fed. Eur. Biochem. Soc.) Lett. 209:321-324.

Wells, D. H., and Long, S. R. 2002. The Sinorhizobium meliloti stringent response affects multiple aspects of symbiosis. Mol. Microbiol. 43:1115-1127.

\section{AUTHOR-RECOMMENDED INTERNET RESOURCES}

The Australian National University Research School of Biological Science Institute of Advanced Studies website: semele.anu.edu.au/2d/Smel.html

The Expert Protein Analysis System (Expasy) website's compute pI/Mw tool: kr.expasy.org/tools/pi_tool.html.

Géonopôle's PRIAM application to Sinorhizobium meliloti proteome web page: genopole.toulouse.inra.fr/ crenard/Proteome_melilo.html.

INRA and CNRS Sinorhizobium meliloti 1021 genome sequencing projects: sequence.toulouse.inra.fr

The Kyoto Encyclopedia of Genes and Genomes (KEGG) database: www.genome.ad.jp/kegg/

Tmpred and Protparam programs on the Expert Protein Analysis System (Expasy) website: www.expasy.ch/tools/ 